\title{
Early Days of Food and Environmental Virology
}

\author{
Dean O. Cliver
}

Received: 29 October 2009/Accepted: 17 January 2010/Published online: 4 February 2010

(C) The Author(s) 2010. This article is published with open access at Springerlink.com

\begin{abstract}
In July 1962, the author joined the Food Research Institute (FRI), then at the University of Chicago, to become its food virologist. There was a limited record of waterborne viral disease outbreaks at the time; recorded data on foodborne outbreaks were fewer still. Laboratory environmental (water and wastewater) virology was in its infancy, and food virology was in gestation. Detection of viruses was most often attempted by inoculation of primary primate cell cultures, with observation for plaque formation or cytopathic effects. Focus was initially on enteroviruses and reoviruses. Environmental and food samples had to be liquefied if not already in liquid form; clarified to remove solids, bacteria, and fungi; and concentrated to a volume that could be tested in cell culture. Cytotoxicity was also a concern. Studies at the FRI and some other laboratories addressed all of these challenges. The FRI group was the World Health Organization's Collaborating Center for Food Virology for many years. Other topics studied were virus inactivation as functions of temperature, time, matrix, disinfectants, and microbial action; peroral and ex-vivo infectivity; and the suitability of various virus surrogates for environmental monitoring and inactivation experiments. Detection of noroviruses and hepatitis A virus required molecular methods, most often RT-PCR. When it was found that inactivated virus often gave the same RT-PCR signal as that of infectious virus, sample treatments were sought, which would prevent false-positive test results. Many laboratories around the world have taken up food and environmental virology since 1962, with the result that a dedicated journal has been launched.
\end{abstract}

D. O. Cliver $(\bowtie)$

University of California, VM:PHR, One Shields Avenue,

Davis, CA 95616, USA

e-mail: docliver@ucdavis.edu
Keywords Environmental virology - Enteric viruses · Food virology $\cdot$ Detection $\cdot$ Inactivation

\section{Introduction}

I am delighted to have this opportunity to share some reminiscences of the evolution of food and environmental virology. Although this is largely a first-person account and subject to the problems of a failing memory, I console myself with the thought that most of what is known of evolution has been learned from old fossils. My research in environmental virology began in 1962. Only virology is addressed in this narrative, although our group worked with other intestinal pathogens (bacteria, protozoa, etc.) at times. My research career has led me to view the world as though peering outward through the anal orifice- - "reverse proctoscopy" has contributed significantly to addressing problems in unusual ways.

The article is divided into arbitrary topic areas because putting the entire record together in chronological order would have been hopelessly confusing. I hope the reader finds some coherence in the scheme that I have chosen.

\section{Early Outbreaks of Foodborne Viral Disease}

Hepatitis A (HA) was formerly called epidemic jaundice and then infectious hepatitis. A waterborne outbreak was reported in the UK as early as 1896 (Plowright 1896). A small outbreak of poliomyelitis that occurred in 1914 in the UK was also recorded (Jubb 1915). Understanding of the nature of viruses was very limited in those early times, and so laboratory testing was not an option and epidemiologic investigations were problematic. By 1967, I was able to 
compile a total of 36 reported foodborne outbreaks of HA and 10 foodborne outbreaks of poliomyelitis (Cliver 1967c). The predominant vehicle for HA was shellfish, as is apparently still the case in many countries. The predominant vehicle for polio was raw milk-this may well have been due to using fecally soiled hands to milk cows and failure to pasteurize the milk, but it is also possible that there was some bias because milk was the vehicle for so many other diseases. Details of these outbreaks and further source references have been compiled elsewhere (Cliver 1967c, 1983). The possible viral causation of "foodborne gastroenteritis of unknown etiology" was also recognized early (Cliver 1969). After World War II, it appeared that water virology progressed faster than food virology, based on the study by the US Public Health Service and others (Berg 1967; Metcalf et al. 1995).

\section{My Entrée}

\section{Universities}

I was born in 1935 and raised in Berwyn, Illinois-a Czech-speaking, close-in suburb of Chicago. Though my upbringing was urban, summer exposures to small-scale dairy farming in central Wisconsin attracted me. I chose to study Dairy Husbandry at Purdue University (BS 1956, MS 1957) and was exposed to laboratory research there. After 6 months of active duty for training as an Army officer, I began doctoral studies in Dairy Science at the Ohio State University in January of 1958. My study was intended to address the transfer of immunity from the cow to the calf in colostrum-the first milk produced after the cow gives birth. Fortuitously, I was assigned to a laboratory in the School of Veterinary Medicine that had begun studying porcine enteroviruses, supported by the Office of Naval Research. The leader of the group was Edward H. Bohl, DVM, PhD, who was willing to expand his studies to include bovine enteroviruses. My mentor in the laboratory was Louis Kasza, DVM, who had left Hungary during the 1956 revolution. His knowledge and laboratory skills were excellent, but his spoken English was somewhat challenging. I had grown up in a community where English was the second language, so I had relatively little problem learning from him. He taught me what were then state-ofthe-art laboratory methods in cell culture and virology. We later became roommates; and still later, he was "best man" at my wedding (Kasza 2003).

Very little that was needed for this study was available from catalogs at the time. In order to study bovine enteroviruses, it was understood that I must produce primary bovine kidney cell cultures. Balanced salt solutions (Hanks' and Earle's) were produced from individual salts, glucose, and deionized water. Medium was either of the salt solutions plus $0.5 \%$ lactalbumin enzymatic hydrolyzate. These were sterilized by autoclaving. Growth medium required addition of $5 \%$ bovine serum, and maintenance medium had $2 \%$ bovine serum. Bovine serum was produced by collecting blood at a slaughterhouse, allowing it to coagulate, and sterilizing the expelled serum by filtration through an asbestos-mat Seitz filter. The kidney to be cultured was collected as aseptically as possible from a freshly slaughtered animal. Only the cortex of the kidney was suitable for culture; since the bovine kidney is lobular, it was necessary to dissect the cortex individually off of each lobe of the kidney. These pieces were minced and mixed with trypsin solution, in an Erlenmeyer flask with a magnetic stir bar. Periodically, cells that had been freed were harvested and sedimented gently in a centrifuge; fresh trypsin solution was added to the flask until enough cells had been harvested to produce a week's cultures. Cultures were grown principally in 4-ounce $(\sim 100 \mathrm{ml})$ prescription bottles closed with white rubber stoppers (Cliver and Bohl 1962a). These were highly compatible with the cells, but required rigorous cleaning if they were used more than once. Unevenness in the glass limited visibility with the microscope and caused at least some problems with distribution of the cells when the culture was seeded and with distribution of virus inoculum during plaque assays. Semisolid overlays for plaquing combined double-strength growth medium with double-strength agar solution and $0.5 \%$ neutral red. When the agar had solidified, the cultures were incubated cell-sideup in darkness at $37^{\circ} \mathrm{C}$ and observed for plaque formation at approximately 2-day intervals. Further details of how individual enterovirus strains were isolated and how quantitative neutralization tests were performed have been published elsewhere (Cliver and Bohl 1962a, b).

\section{Fort Detrick}

My PhD was awarded in March of 1960, and I stayed the rest of that year doing postdoctoral amplifications of our findings. After a 6-month hiatus, I joined the U.S. Army Biological Laboratories, Fort Detrick, Frederick, Maryland, as a National Academy of Sciences-National Research Council Resident Research Associate. During a year there, I learned the then-accepted procedures for working with highly pathogenic agents; most of these procedures are now obsolete. My own research concerned the kinetics of neutralization of Semliki Forest virus by rabbit antiserum, as measured in primary cultures of chicken embryo fibroblasts. Chicken embryos (9-10 days incubated) to be cultured were received in the shell and were decapitated, minced, and trypsinized more or less as described above. Although plastic cell-culture flasks had become available, their failure rate was so high in those early years that they 
were not permitted for use at Fort Detrick, for fear of contaminating an entire incubator with leaked virus suspension. Soft-glass prescription bottles continued to be the vessel of choice: at least they were only used once. I was not encouraged to publish my research findings, at least partly because Fort Detrick was a relatively secretive establishment. Meanwhile, the fact that my wife and I were of disparate races had made our life in Frederick unpleasant, and so we determined to move on. Up to this point, I had decided that I would like to continue in virology, not necessarily with veterinary applications.

\section{University of Chicago}

While I was exploring other opportunities, I was invited to meet two visiting faculty members (Dr. Merlin S. Bergdoll and Dr. Hiroshi Sugiyama) from the Food Research Institute (FRI) of the University of Chicago (UC), who were consultants at Fort Detrick. I learned that the founder and director of FRI, Dr. Gail M. Dack, had decided to add viruses to the foodborne pathogens being studied at FRI. I was fortunate to be interviewed and promptly offered a position as "Research Associate (Instructor)," beginning July 1, 1962. The job description was necessarily vague, as no one knew what a food virologist was at the time-least of all me. History was also difficult to explore, in that there was no Internet and all the needed information was recorded in books, on cards, and on pieces of paper, not all of which were readily available at any given time.

We began by trying to obtain suitable human placentas for culture, from the obstetrical facility at the Chicago Lying-in Hospital, which was part of the UC Medical School. After several culture failures, I was told that these placentas were inevitably slathered with tincture of green soap. Colleagues on the medical school faculty had already cornered the supply of "clean" placentas from voluntary hysterectomies. The alternative was monkey kidney. Dr. Bergdoll maintained a colony of approximately 100 rhesus monkeys (Macaca mulatta), which were used in detecting staphylococcal enterotoxins and determining the mode of enterotoxin pathogenesis. After a few experiments, an animal would become refractory to the enterotoxin and of no further use to that project. We arranged to purchase these "alumni" as kidney donors. We then learned from experience that the monkey house had a high population of airborne yeasts, which would contaminate the kidneys collected in the animal facility and were resistant to our antibiotics. We had to collect the kidneys with their capsules intact and carry them back to the laboratory in a beaker of Dakin's solution (a strong, buffered solution of hypochlorite). At the laboratory, sterile saline was used to rinse away the hypochlorite before the capsules were opened. The kidneys were relatively small and costly, and so we tried culturing the medullas along with the corticesit did not work. Thereafter, the cortices were dissected off of the kidneys and used as the sole source of tissue for primary culture. One of the medical school faculty members routinely harvested the primary cultures and made secondary cultures to amplify the supply obtained from one monkey. Our trials of this method did not yield the desired results, and so we simply digested the tissue as extensively as possible, obtaining enough cells to produce $200-240$ of $25-\mathrm{cm}^{2}$ cultures (in styrene flasks) from one monkey. Cultures were also grown in $16 \times 150 \mathrm{~mm}$ test tubes (in slanted racks that confined the medium and the cells near the butt of the tube) and in Leighton tubes, which contained a coverslip near the butt end, on which the cells were grown to provide superior microscopic imaging. Our methods were later described in detail (Cliver and Herrmann 1969), as well as a machine for changing the medium in the cultures during their outgrowth period (Cliver 1973a). Our research at UC was funded by food industry donations to FRI and a small grant from the US Public Health Service. My application to renew the grant was unsuccessful.

\section{University of Wisconsin}

In 1966, on the occasion of Dr. Dack's retirement as Director, UC evicted the entire FRI on the grounds that our research was too applied to merit space on their campus. Fortunately, we were invited to join the University of Wisconsin (UW) at Madison, under the directorship of Dr. E. M. Foster. The facilities into which we moved could best be described as a work in progress.

\section{Detection in Cell Cultures}

The evolution of tissue/cell culture was very much a work in progress at this time. Explants had earlier been embedded in plasma clots and maintained with various fluid media while cells migrated outward in a single layer that could be viewed with a microscope. Primary cell cultures were prepared by digesting animal tissue to component cells, using trypsin or other enzymes, often enhanced with versene (ethylene-diamine-tetracetate) as a chelator. The cells thus freed were washed and planted in sealed glass vessels in medium typically based on either Hanks' or Earle's balanced salt solution - these had a physiologically balanced content of cations (sodium, potassium, calcium, and magnesium) with chloride ions and a phosphate buffer system, plus glucose. Adjustment of $\mathrm{pH}$ was done with varying levels of sodium bicarbonate: Earle's solution was formulated for higher levels of bicarbonate, which was useful as cell populations built to a level where their 
metabolic acid needed more neutralization. Cell culture vessels (e.g., flasks, bottles, tubes) were sealed because the bicarbonate buffer equilibrated with $\mathrm{CO}_{2}$ in the vessel's airspace: if the $\mathrm{CO}_{2}$ escaped, then the sodium bicarbonate became sodium hydroxide, and the $\mathrm{pH}$ climbed and killed the cells. When incubators were invented that maintained a $5 \% \mathrm{CO}_{2}$ atmosphere in their interiors, cells could be grown in unsealed containers (e.g., Petri plates), but there were (are) always risks that the controls would fail, resulting in the death of the all of the cultures. Various media with $\mathrm{CO}_{2}$-free buffer systems have been devised, but $\mathrm{CO}_{2}$ has not yet been entirely replaced. One formulation substituted galactose for glucose so as to inhibit acid production by the cultured cells.

Nitrogen sources could be as simple as enzymatic hydrolyzate of bovine lactalbumin, which worked well with various primary cultures and was inexpensive and autoclavable. Medium 199 was a pioneer synthetic medium that contained virtually all the known chemical constituents of mammalian tissue, including nucleic acid bases; most of its ingredients are not known to be required by cells in vitro, and it was a huge project to compound from individual chemicals, but it is still used to some extent now that it can be bought from catalogs. A turning point was the research by Harry Eagle to determine the specific nutritional needs (amino acids and vitamins) of a selected cell line. He devised Basal Medium Eagle in a version for his line of HeLa cells, and another for his line of L-cells. The next step was the development of Minimum [sic] Essential Medium, which would meet the needs of a variety of cell lines. An additional solution of "Nonessential Amino Acids" was devised for planting new cultures and for lines that had special needs. Some researchers use these nonessential additives routinely. Another persistent component of cell culture media is animal blood serum-often, but not always, derived from fetal calves at present. Serum-free media have been developed, but the majority of medium formulations still include serum. The degree to which bovine serum enhances growth of cells of other animal species is remarkable.

The transition between primary cultures and established cell lines is large. Once animal tissue (often kidney cortex, as mentioned above) is broken down and the dispersed cells planted in a culture vessel, some of the cells settle to the glass or plastic surface, attach, spread, and multiply until a confluent monolayer of cells is formed. This is almost entirely fortuitous - the selection of cells that attach to the growing surface (those that do not are discarded at the first medium change) and multiply, and why they ideally stop multiplying when the monolayer is complete (the so-called contact inhibition) are beyond the control of the scientist, although the preparation of growing surfaces for this purpose is now well understood. In the case of the monkey species from which kidney cultures played such a key role in poliomyelitis research, it is said that poliovirus did not infect upon direct injection into the kidney of a living monkey. One can harvest cells from primary culture in a number of ways, dilute them in fresh growth medium, and plant a larger number of secondary cultures with a high probability of success. However, subsequent passages fail more often than not, and so the establishment of a durable cell line requires considerable tenacity. Primary cell cultures were considered better for production of vaccines, even though primary monkey kidney cells often harbored adventitious simian viruses that might threaten the vaccinee, because established lines were suspected of having undergone a malignant transformation. Primary cells were also widely used in food and environmental virology because they often had a wider virus-susceptibility spectrum and a greater tolerance for toxic substances in field samples than did available established lines. "Diploid" cell lines were developed which were said to preserve the karyotype of the source species: these tended to grow slowly and sometimes develop karyotypic abnormalities. Established lines, such as the venerable HeLa, have recognized identity, but they too are affected by selective pressures during repeated passage in any given laboratory, whereby they may acquire an identity that varies from what would be obtained under the same name, say, from the American Type Culture Collection.

In many applications of cell cultures to virology, all that was required was scrupulous aseptic technique. However, recovery of viruses from foods and from environmental samples inevitably entails elimination or suppression of contaminating bacteria and perhaps other microbes. Antibiotics often serve this purpose; treatment of the sample extract with chloroform is often feasible, in that most enteric viruses are un-enveloped and not damaged by some of the organic solvents. Membrane filters have now evolved to the point that they can serve to remove bacteria, mold spores, yeasts, etc. very reliably.

Increasingly, in recent times, cultures of tissues other than kidney have given rise to lines that have special applications. And, as will be described later, explant cultures may serve special purposes, where the in vivo organization of the tissue is significant to the investigation.

At UC, we had cell cultures and a variety of viruses obtained from the Viral and Rickettsial Registry of the American Type Culture Collection and from colleagues. The focus was on enteroviruses, but our first published method for virus detection in cell culture was done with reovirus type 3 (RE3) (Gibbs and Cliver 1965). Reoviruses were newly identified and perceived as a threat to human health at the time. The method of detection in cell culture was based on staining the infected cells (on a coverslip from a Leighton tube) with acridine orange, which 
associates with nucleic acids and fluoresces red-orange with single-stranded nucleic acids and yellow-green with double-stranded nucleic acids. RE3 infection tended to cause the host cells to spread to larger-than-usual proportions in the monolayer; viral inclusions formed in the cytoplasm and fluoresced yellow-green (because reoviral RNA is double-stranded) against the orange fluorescence of the rest of the cytoplasm. With careful scanning on a fluorescence microscope, a single infected cell could be detected on a coverslip. The principal drawback of the method was tedium. Some preliminary concentration methods were also explored: adsorption to and elution from bovine RBC, dialysis against polyethylene glycol, and preparative ultracentrifugation. Adsorption to bovine RBC is unique to RE3; the other methods found broader applications and will be discussed in the next section.

Detection of viruses by inoculation of cell cultures may be based on plaque formation or production of cytopathic effects (CPE); other things being approximately equal, the two methods are equally sensitive (Kostenbader and Cliver 1973). Limitations are the susceptibility of the inoculated cells to the virus that happens to be present, and the volume of inoculum that can be tested in single culture. Where more than one cell culture type was needed to cover the spectrum of viruses of concern, we tried mixing two types of cells in a single culture but later learned that the inoculum could be harvested from a cell culture of one type, after an appropriate adsorption period, and transferred to a culture of another type with little loss of infectivity, and that much larger volumes of inoculum than usual could be tested per cell culture flask, under the right conditions, by the CPE method (Kostenbader and Cliver 1977, 1986).

\section{Concentration Methods}

Viruses are very small and are likely to occur in the environment in large volumes of water or in problematic food matrices. The default detection method was to infect susceptible cell cultures, which have a limited capacity for sample volume, a low tolerance for food residues, and the high susceptibility to contaminating bacteria and molds. We and others faced the challenge of concentrating virus from large volumes of fluid suspension, perhaps after separating the virus from a solid food sample.

\section{Ultracentrifugation}

In the early 1960s, working-class preparative ultracentrifuges were becoming available, and we were able to get one. This represented a "brute-force" approach to virus concentration, with as much as $100,000 \times g$ to sediment the virus. The forces were massive, but there was a tendency for the sediment to stir back into the supernatant as the rotor decelerated, even with the brake off. We determined that a $2 \%$ solution of gelatin was solid at $4^{\circ} \mathrm{C}$ and liquid at $20^{\circ} \mathrm{C}$. This was used to install a $0.1-\mathrm{ml}$ "trap" at the point in the tube farthest from the axis of rotation. The rotor and sample were pre-chilled, so that the trap remained solid until the end of the run. Then, the cap was removed from the tube and the supernatant poured off; the trap was liquefied and collected in a small volume of sterile diluent. This was quantitatively efficient, but the volumes of virus suspension that could be processed in a 1-2-h run were relatively limited (Cliver and Yeatman 1965; Gibbs and Cliver 1965). There was also the problem of an occasional "catastrophic disassembly event"-the ultracentrifuge manufacturer's euphemism for disintegration of the rotor at speed. This happened twice in our ultracentrifuge; although no one was hurt, cleaning, disinfection, and reconstruction were very problematic.

\section{Polyethylene Glycol Dialysis}

We also tested a procedure whereby the virus suspension was sealed in dialysis tubing and immersed in a 50\% solution of polyethylene glycol (PEG). This could be done with virtually any virus and any number of samples (PEG was inexpensive), but harvesting the samples typically awaited the following day (Cliver 1967a; Gibbs and Cliver 1965). There was the additional problem that if PEG contaminated the concentrated sample, the sample would intoxicate the inoculated cell culture. It was necessary to rinse the outside of the dialysis tubing carefully before opening it; we also devised a wringer apparatus that would force the concentrated sample to the open top of the dialysis tube for aseptic collection.

Eventually, we undertook to combine PEG dialysis with ultracentrifugation. A wide-mouth funnel was inserted into the ultracentrifuge tube, and a cast cylinder of PEG was inserted into a dialysis tube that extended from almost the bottom of the ultracentrifuge tube to the top of the funnel. When a 100-ml sample was poured into the funnel, excess fluid was imbibed by the PEG inside the dialysis tube until the total volume could be contained by the ultracentrifuge tube. At this point, the funnel and the PEG-containing dialysis tube were removed, and the ultracentrifuge tube was capped and placed in the rotor (Herrmann and Cliver 1968b). This approach was not compatible with use of the trap described above.

\section{Membrane Chromatography/Viradel}

Another important development at that time was the introduction of cellulose-ester membrane filters, which could be stored in the dry state and sterilized by 
autoclaving. Cellulose nitrate (gun cotton) had long been in use as a component of smokeless gunpowder-no accidents seem to have occurred with the filters. Some of the filters were said to comprise pure cellulose nitrate, while others were composed of mixed esters of cellulose, with nitrates predominating. These represented a huge advantage from the standpoints of convenience and reliability. They were produced in a great array of nominal pore sizes, based on the size particles that would pass through and on the pressure required to force air through water-wet filter. The pores themselves were not uniform, and the filters resembled a sponge $150 \mu \mathrm{m}$ thick, but their ability to retain or reject particles larger than their nominal pore size was phenomenal. A distinguished diagnostic virologist, G. D. Hsiung, soon put this rejection capability to work in classifying unknown viruses (Hsiung 1965; Hsiung and Henderson 1964). According to her scheme, small viruses would pass a nominal 50-nm filter, medium viruses would pass a nominal 100-nm filter but not the $50 \mathrm{~nm}$ filter, and large viruses were completely retained by a filter of $100-\mathrm{nm}$ porosity. She noted that these properties were qualitative, in that small viruses, for example, would be found in the filtrate of the 50-nm filter, but a large proportion of the viral particles were retained in the filter matrix. We were able to show that adding a small proportion of animal serum to the virus suspension obviated such retention (Cliver 1965a).

Given that the affinity of the membranes was such that they might retain more than $99 \%$ of the virus, it occurred to me that this might afford a basis for concentration of viruses from fluid suspension, assuming that means could be found to elute the virus from the filter matrix. We used an eluent of $30 \%$ agamma chicken serum in phosphate-buffered saline (PBS) and reported a $50 \%$ probability of detecting coxsackievirus A9 (CA9) in tap water at the level of 2 PFU per liter (Cliver 1967b). These results were summarized at a 1965 symposium (Transmission of Viruses by the Water Route) convened by Dr. Gerald Berg in Cincinnati and hosted by the Federal Water Pollution Control Administration, falling within the US Department of Interior. I coined the term "membrane chromatography" for this process: I had done column chromatography previously, and I envisioned the membrane as a cylinder with an extreme height-to-diameter ratio. More recently, "virusadsorption-elution" has been contracted to "viradel." Advance notice of our study resulted in several discussants mentioning experiments that basically corroborated our report. At that point in my career, I did not realize that publication in a proceedings volume was not equivalent to publication in a refereed journal; worse yet, the proceedings volume did not appear until 1967 (Berg 1967). I also suffered from inability to think big-since that time, many innovations have been added, some of which have not stood the test of time, commercial versions have been developed, and adsorption-elution has become the basis for large-scale official water testing methods of the US Environmental Protection Agency (EPA-EPA 2001). I had little input to these developments.

\section{Phase-Separation, Precipitation}

Another procedure for concentrating enteric viruses from dilute suspension-the aqueous polymer two phase system-was also being studied seriously during the 1960 s (Philipson et al. 1960). Two groups reported their studies of this method at the 1965 symposium (Lund and Hedstrom 1967; Shuval et al. 1967)), and one reported further study in a journal (Lund and Hedstrom 1966). The method entailed adding polyethylene glycol 6000 and sodium dextran sulfate to the sample; the thoroughly mixed suspension was placed in a cold room to separate for 18-24 h, and the small, lower phase (formed by the sodium dextran sulfate) was harvested and tested for virus. We tested the procedure with seven types of enteroviruses plus influenza A virus and found that the sodium dextran sulfate was apparently inhibitory to coxsackievirus B2, echovirus 6 (EC6), and influenza A virus (Grindrod and Cliver 1969). The last of these was probably of no consequence, but the inhibitory action of the sodium dextran sulfate seemed likely severely to bias surveys of water or wastewater such as had been reported previously (Lund and Hedstrom 1967). We later showed that substituting dextran T-500 for the sodium dextran sulfate mitigated the inhibition problem (Grindrod and Cliver 1970); however, the method was relatively ponderous and slow; so it found limited use. It eventually developed that viruses could be precipitated with polyethylene glycol, without dextran for phase separation (Lewis and Metcalf 1988).

\section{Other}

We later did some study on antibody capture (Deng et al. 1994) and on immunomagnetic concentration of hepatitis A virus (HAV) (Jothikumar et al. 1998; López-Sabater et al. 1997) and were able to show that the urea-argininephosphate buffer that had been used successfully to elute human viruses adsorbed to filters was also applicable to phages (Jothikumar and Cliver 1997).

\section{Irradiation}

Very early in my tenure with FRI, I was invited to review knowledge of irradiation of viruses, as it might pertain to food preservation (Cliver 1965b). Some irradiation-inactivation results were presented at the 1965 water symposium, but these were not for viruses that were likely to be foodborne (Sharp 1967). Picornaviruses and caliciviruses 
present extremely small targets and are thus likely to require large doses of ionizing irradiation to achieve substantial degrees of inactivation (Kaplan and Moses 1964). Predictability of "kills" is further complicated by the tendency of viruses to aggregate, whereby an infectious unit may comprise two or more virions, all of which must be inactivated before the infectivity of the unit is lost (Berg et al. 1967; Chang 1967). Studies we did with support from the US Atomic Energy Commission seemed to indicate that a low dose of ${ }^{60} \mathrm{Co}$ gamma-rays had induced both a host range and an antigenic mutation in CA9 (Cliver 1968), but the results were not repeatable. We later learned that CA9 was rather idiosyncratic among enteroviruses (Herrmann and Cliver 1973a). More extensive virus irradiation studies were conducted in the Virology Branch of the US Food and Drug Administration (FDA-Sullivan et al. 1971), who later reported that radiation sensitivity was lower in ground beef than in cell culture medium (Sullivan et al. 1973).

Irradiation of shellfish was considered as a means to control bacterial contaminants (Licciardello et al. 1989) Vibrio parahaemolyticus should be a special concern, as its presence is not related to fecal contamination of the growing water. In this connection, the irradiation process was examined as to its probable effect on contaminating enteric viruses. This was a time when aquarium studies of virus uptake and depuration of shellfish were rare (Power and Collins 1989), and so it was an accepted practice to inject virus into the soft tissue (no specific organ) of shellfish for irradiation. A first such study was conducted in the ${ }^{60} \mathrm{Co}$ irradiation facility of the University of Lowell, Massachusetts, with HAV and rotavirus in hard-shell clams (Mercenaria mercenaria) and eastern oysters (Crassostrea virginica) (Mallett et al. 1991). Viruses produced at the Baylor College of Medicine were inoculated into the shellfish at the University of Lowell (no details given), irradiated, shucked, and shipped back to Baylor for assay. The virus extraction process was not described. Decimal reduction $\left(\mathrm{D}_{10}\right)$ values of $2.0 \mathrm{kGy}$ were reported for HAV, and $2.4 \mathrm{kGy}$ for rotavirus; irradiation of live, un-inoculated shellfish at these doses was said to have minimal adverse effects on their viability and their palatability after various styles of cooking.

We were offered a small grant by the International Atomic Energy Agency to look further into this process. With this and limited support from other sources, we planned to produce the viruses in Madison and send them to Lowell to be inoculated into the shellfish and irradiated as was done in the earlier study, with the soft tissue shipped back frozen for assay in our laboratory. Extraction of the virus was to be done by our "Cat-Floc" method (Kostenbader and Cliver 1981). Because of the high cost of irradiation, we mixed poliovirus 1 (PO1) with HAV, so that they could be inoculated and irradiated together. When the virus mixtures were inoculated onto FRhK-4 cell monolayers, $\mathrm{PO} 1$ plaques were seen within 5 days; however, if the mixture was treated with anti-PO1 antiserum before inoculation, then HAV plaques were seen at approximately 16 days of incubation, and the PO1 was not expressed. This also worked with the shellfish extracts- to our knowledge, this approach has not been used by others, although mutually exclusive host systems have permitted inactivation studies on mixtures of two animal viruses and two phages (Olivieri et al. 1983). The first shipment of viruses was lost in transit to Lowell, so another had to be sent. Eventually, the samples arrived back in Madison for extraction and assay. Calculated $\mathrm{D}_{10}$ values for viruses in clams (PO1, $5.43 \mathrm{kGy}$; HAV, $5.95 \mathrm{kGy}$ ) were higher than those reported by others (Fig. 1), perhaps due to matrix effects and the different extraction procedure. Unfortunately, the laboratorian (Kenneth D. Kostenbader, Jr.) developed a fatal illness, and the oyster samples were not assayed, nor have the results presented here been published elsewhere.

\section{Hepatitis A Virus}

James Mosley, then chief of the Hepatitis Unit at the Communicable Disease Center (now Centers for Disease Control and Prevention-CDC), stated in 1965 that infectious hepatitis. (now hepatitis A-HA) was the only viral disease for which there was expert consensus in favor of waterborne transmission, although he also considered the possibility of waterborne poliomyelitis (Mosley 1967). He tabulated 50 waterborne HA outbreaks worldwide; he also stated that 14 foodborne HA outbreaks had been recorded in the USA from 1952 to 1964 . In those years, diagnosis was based on clinical signs and on serum transaminase levels-there was no direct test for HA (Cliver 1966). Another problem in investigating common-source outbreaks of HA is the long incubation period (15-50 days, median 28 days), which challenges the victims to remember what they have eaten and the epidemiologists to create a coherent record of events. Once the frequent association of HA with raw shellfish consumption was recognized, it became routine to ask about shellfish consumption when HA was diagnosed: this may have imposed some bias against identification of other potential vehicles. By the publication of the WHO Manual on Food Virology in 1983, we were able to tabulate 153 foodborne HA outbreaks recorded between 1943 and 1982, as well as 117 waterborne HA outbreaks between 1895 and 1980 (Cliver 1983).

Research with HAV in our laboratory awaited the development by others of means to do the investigations we desired. Although HAV had been propagated in cell culture as early as 1979 (Provost and Hilleman 1979), it 

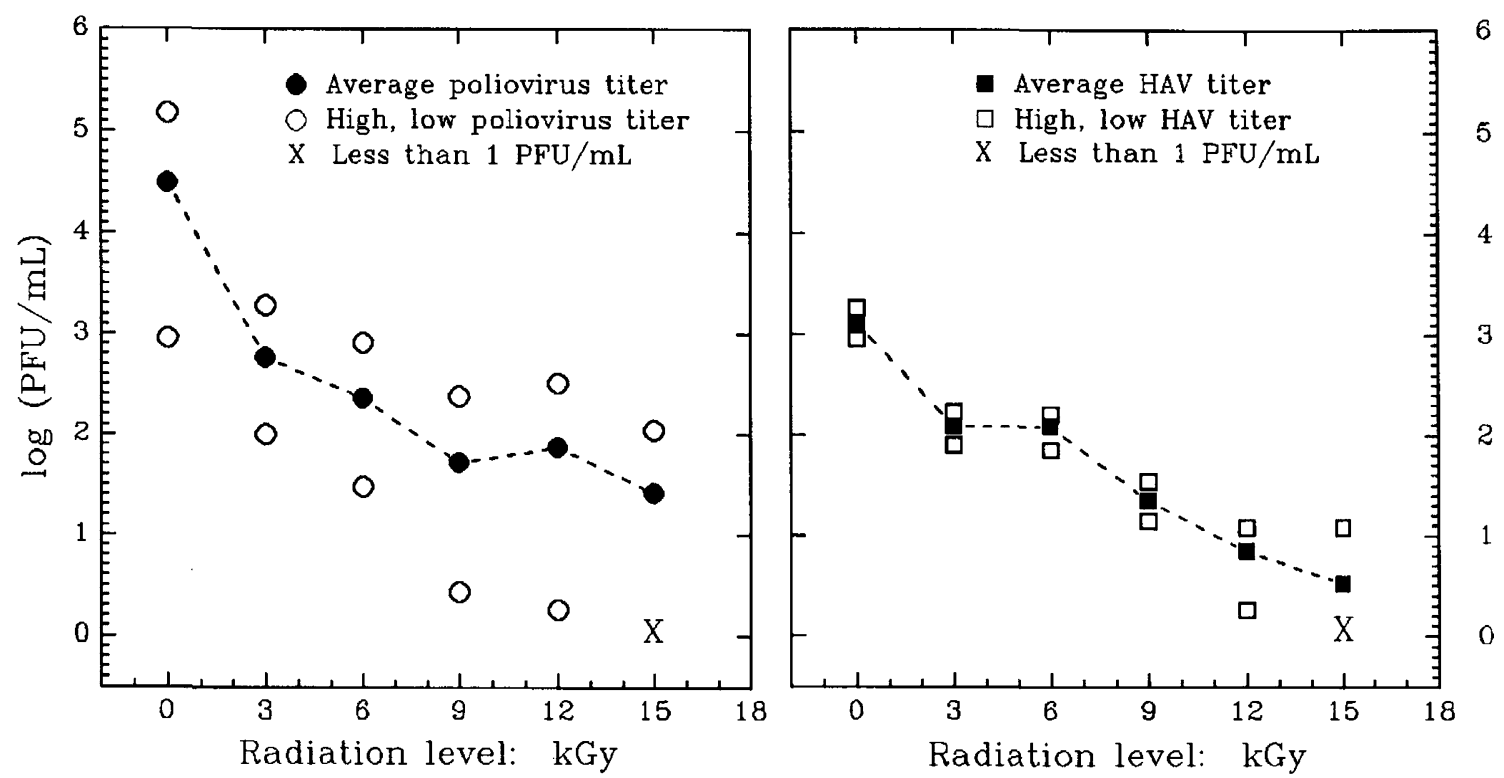

6

2

Fig. 1 Inactivation, by ${ }^{60} \mathrm{Co}$ gamma rays, of poliovirus and HAV experimentally inoculated into clams (Mercenaria mercenaria)

was not until 1972 that a combination of an HAV strain and a cell culture strain that resulted in cytopathic effects and plaque formation reported (Cromeans et al. 1987). A good deal of study on foodborne HAV had been done in the early 1990s (Cromeans et al. 1994). Our eventual contributions included development of an immunomagnetic method for detecting HAV in oysters (López-Sabater et al. 1997), disinfection studies with $\mathrm{ClO}_{2}$ (Mariam and Cliver 2000a), and demonstration that HAV is only $\sim 90 \%$ inactivated by pasteurization in raw milk (Mariam and Cliver 2000b).

\section{Food Matrix}

It was clear from the outset that food matrices presented special problems with respect to virus detection. Quite small quantities of virus needed to be separated from the solid phase of the food sample (and any incident microflora), concentrated to a small volume of fluid, and inoculated into a susceptible cell culture. There were no concerns at that time regarding PCR inhibitors, but many other complications. Shellfish were an early concern because of their association with outbreaks of HA (Koff et al. 1967; Mosley 1967). T. G. Metcalf, then at the University of New Hampshire, pioneered laboratory studies on the association of enteric viruses with oysters (Metcalf and Stiles 1965). He made several further contributions to environmental and shellfish virology there and after his move to the Baylor College of Medicine (Atmar et al. 1995, 1996; Metcalf and Stiles 1967, 1968; Metcalf et al. 1979, 1980a, b, 1995).
Because our group was in Chicago and then Madison, far from the sea, our attention was often directed to foods other than shellfish. We considered that foods might be liquids, or solids that could be contaminated in depth, or solids with superficial contamination limited to a relatively impermeable surface. The most challenging of these would be solids that could be contaminated in depth-our first model system comprised cottage cheese and CA9 (Herrmann and Cliver 1968a). An inoculated, 25-g sample was slurried with $100 \mathrm{ml}$ glycine- $\mathrm{NaOH}$ buffer, treated with Freon TF (1,1,2-trichloro-1,2,2,-trifluoroethane) and bentonite, clarified by centrifugation, and concentrated by a two-stage (PEG dialysis followed by ultracentrifugation) process that yielded $0.5 \mathrm{ml}$ for testing in cell culture. Virus recoveries from the samples inoculated with $50 \mathrm{PFU}$ or less were roughly $50 \%$, as determined by the plaque technique. In addition to cottage cheese, the method was then adapted and tested with beef with gravy, carrots, chicken pot pie, chocolate éclairs, clams, ground beef, peanut-butter sandwiches, potato salad, and strawberries. The beef with gravy and the peanut-butter sandwiches had been freeze-dried to be fed to astronauts early in the US space program (Herrmann and Cliver 1968b). Viruses inoculated included CA9, coxsackievirus B3 (CB3), and EC6; poliovirus 2 was used in experiments on recovery of antibody-neutralized virus. Not surprisingly, optimal extraction methods varied among foods, with bentonite omitted and serum substituted for low-protein foods. Recoveries of EC6 were somewhat less than those for the coxsackieviruses. Overall, it was found that a 25-g food sample must contain at least 3-4 PFU for a $50 \%$ probability of detecting virus. We supposed that viral 
contamination of tomatoes would be largely limited to the surface, so we devised an apparatus that would dislodge virus from the tomato surface without suspending the food solids in the extract (Cliver and Grindrod 1969). Surface dirt, fecal solids from the model contaminant, and a variety of bacteria appeared in the washings and had to be dealt with before the concentration step; recoveries of CB3 were roughly $49 \%$, with a $50 \%$ endpoint, for a positive test result, of slightly under 2 PFU per tomato.

At the request of the Calgon Company of Pittsburgh, we tested a product called Cat-Floc (a polydimethyldiallyl ammonium chloride, MW $\sim 500,000$ ) for virus removal when used as a primary coagulant or coagulant aid in treatment of drinking water and wastewater (Cliver 1971). Results were encouraging, and we were left with a great deal of the product when the trials ended. Oysters (Crassostrea virginica and Ostrea edulis) were experimentally inoculated with enteroviruses and minced with scissors, then stirred with $100 \mathrm{ml}$ PBS to which was added $2 \mathrm{ml}$ of a $1 \%$ Cat-Floc solution; after 5 min of stirring and $15 \mathrm{~min}$ of settling, the suspension was filtered by pressing in a potato ricer (Kostenbader and Cliver 1972). The extract could be concentrated by ultracentrifugation or ultrafiltration. Quantitative virus recoveries exceeded $80 \%$, but it was shown that poliovirus neutralized with coproantibody was not reactivated by this process. CA9, coxsackievirus B2, and EC6, which had been inhibited in previous studies with polymers (Grindrod and Cliver 1969, 1970), were not affected by the Cat-Floc. A number of other groups have since used Cat-Floc in extracting viruses from mollusks, crustacea, and estuarine sediments (Johnson et al. 1981; Landry et al. 1982; Richards et al. 1982; Seidel et al. 1983; Wait and Sobsey 1983).

A filter called ACG/B (activated carbon particles in a matrix of cellulose and glass fibers, H. R. Reeve-Angel, Clifton, N.J.) was tested with and without Cat-Floc for recovery of CB1, EC6, and PO1 from a variety of foods (Kostenbader and Cliver 1973). Meat products included ground beef and frankfurter sausages; chicken salad served as a representative mixed meat product; fresh vegetables included lettuce and carrots; flour products were creamfilled cakes and bread rolls; seafoods comprised oysters (Crassostrea virginica) and clams (Mercenaria mercenaria); dairy products included creamed-curd cottage cheese and cheddar cheese. Filtrates could be filter-sterilized $(0.20 \mu \mathrm{m}$ porosity) and concentrated before testing in cell culture; recoveries of at least $80 \%$ were recorded with optimal selection of procedures. In a later version, the Whatman GF/F glass fiber filter was substituted and a great number (seven dry-form and 13 liquid) of polyelectrolytes were compared for recovery of PO1 from ground beef (Kostenbader and Cliver 1981). Cat-Floc T performed best among the liquids (88\% recovery), and Cation 105C (ICI
America, Wilmington, Del.) was the best of the dry-form flocculants (107\% recovery). Cat-Floc was also found useful in the recovery of reovirus 1 from ground beef ( $\geq 73 \%$ recovery) and oysters (C. virginica, $\geq 50 \%$ recovery). Reviews comparing the various extraction and detection methods as applied to different foods were published in the Journal of Food Protection (Cliver et al. $1983 \mathrm{a}, \mathrm{b})$ and in various editions of the Compendium of Methods for the Microbiological Examination of Foods (Cliver 1976; Cliver et al. 1984, 1992; Richards and Cliver 2001).

\section{World Health Organization (WHO)}

The first WHO support for our food virology study was received at UW in 1967; it came from the Veterinary Public Health (VPH) division, which had primary responsibility for food safety at that time. Our principal contact at the time was Dr. Z. Matyáš, who was then the Food Hygienist in VPH. In September of 1969, I was invited to chair a small informal consultation on virus transmission via foods at the WHO in Geneva; most of those present studied animal viruses that might occur in foods, rather than viral pathogens of humans. I was appointed a WHO consultant on virus transmission through foods on that occasion-a designation that may still survive, but is not active. Further informal consultations were held in Geneva and in Brno, Czechoslovakia, over the next few years. In addition to nominal support for our research in food virology, WHO wanted an international system of information sharing, based eventually in our group. We were the Data Collection Centre for Food-borne Virus Disease and Research on Viruses in Foods, World Health Organization Food Virology Programme, from 1971 to 1975, after which we were designated the World Health Organization Collaborating Centre on Food Virology. What evolved was a three-part program: (1) the Data Collection comprised edge-punch cards, preprinted in the UK, on which bibliographic information and abstracts of pertinent publications were recorded with a typewriter; (2) a Request for Specific Information form was designed and made available to investigators worldwide, to be completed and mailed to Madison for response from the Data Collection; and (3) a List of Food Virologists, compiled largely from authors of articles in the Data Collection. Authors were contacted by mail at their address of record and asked to provide complete contact information and a brief ( $\leq 25$ words) description of their study. When as many responses had been received as seemed likely to come, a List was compiled and mailed to everyone on it. New Lists were undertaken at roughly 2-year intervals. This was a time when there were no computers, word processors, or 
Internet available, and so everything was done on paper and distributed by post. We issued an Information Alert, listing recent, pertinent publications, to members of the List at least annually. The edge-punch cards that were the Data Collection were roughly $12.5 \times 40 \mathrm{~cm}$, with holes along two edges that could be coded and opened to the outside of the card, for sorting with a long needle; obviously, the system of classification was limited in precision and scope. All the same, a few aspiring food (and water) virologists did avail themselves of the service, and we responded as best we could with our limited personnel. Details of these efforts appear in the WHO Manual on Food Virology (Cliver 1983). The nominal financial support from WHO eventually ended, but we chose to keep the system going. To the extent that the program had any impact on environmental virology or public health, it was largely due to the efforts of the late Kenneth D. Kostenbader, Jr., who had a penchant for details. Our reporting channel changed from WHO Geneva to the Pan American Health Organization (PAHO), the WHO Regional Office for the Americas, in 1982. PAHO VPH was then based in Washington DC but has since moved to Rio de Janeiro. Although the distance was less, communications with PAHO's VPH were less close than former interactions with WHO Geneva. We did host the Pan American Health Organization Technical Working Group of Directors of Collaborating Centers Concerned with Food Safety in 1993 in Madison, at their request.

Our designation as a WHO Collaborating Centre ended when we left Madison in 1995. Further application to PAHO led to our designation as the World Health Organization Collaborating Center for Food Virology at UCD from 1997 to 2007. We convened the Meeting of the Technical Working Groups of the WHO Collaborating Centers for Food Safety in Davis in 1998. With the advent of the Internet and the needed technical support, we largely shifted our information services to our web site: http:// faculty.vetmed.ucdavis.edu/faculty/docliver/foodsafetylab. htm. Included are the terms of reference under which our collaborating center operated, the latest version of the List of Food Virologists, and EndNote libraries on viruses and prions and on protozoa.

\section{Laboratory Procedures}

Not all of the methods we developed were applicable only to food and environmental virology. Because of our chronically impecunious situation, we tried to devise cell culture methods that saved costs and labor (Cliver 1973a; Cliver and Herrmann 1969). We determined to what extent the purchased cell cultures could substitute for those grown in one's own laboratory (Kostenbader and Cliver 1979).
The ability of membrane filters to adsorb virus efficiently afforded a rapid method to estimate the specificity of radioactive labeling of virus-nuclide that was not virus associated was found in the filtrate (Herrmann and Cliver 1973c). We also devised an electrophoretic method for collecting viral particles on a polycarbonate membrane so that the particles could be enumerated by scanning electron microscopy (Heinz et al. 1986).

\section{Viruses in Space}

Some of our earliest studies on recovering viruses from foods had been sponsored by the US Air Force School of Aerospace Medicine (Herrmann and Cliver 1968a), which explains the inclusion of two freeze-dried foods that had been developed for astronauts (Herrmann and Cliver 1968b). Subsequently, we were contacted by the life support groups of the US National Aeronautics and Space Administration (NASA) regarding both astronaut foods and the spacecraft water supply. Electricity aboard spacecraft was generated by hydrogen-oxygen fuel cells, so that the water produced as a byproduct was available for drinking and for rehydration of foods that had been freeze-dried to save weight. The food studies were largely precautionaryNASA had a great many "what-if" concerns at that time. Low-moisture foods studied included bacon squares, beef bites, cheese sandwiches, spaghetti with meat sauce, and banana pudding (Cliver et al. 1970). Viruses tested included influenza virus type A (strain PR8), parainfluenza virus type 3 (strain SF-4), reovirus type 1 (strain Lang), EC6 (strain D'Amori), and various polioviruses (some in the feces of infants who had received the trivalent oral polio vaccine). The influenza, parainfluenza, and reoviruses persisted for $\leq 3$ days in inoculated low-moisture foods; whereas the enteroviruses persisted $>2$ weeks at room temperature, and $>2$ months in the refrigerator. Various other temperature-storage regimes were also evaluated; poliovirus of fecal or cell-culture origin behaved similarly. Fecal poliovirus was inactivated $10^{-2}$ during freeze drying in cream-style sweetcorn, but the residual virus persisted with little loss during 15 weeks' storage at $5^{\circ} \mathrm{C}$.

The water-system studies were inspired by a technological problem. Although the water produced by the hydrogen-oxygen fuel cells had $<1$ ppm total solids, it was mixed with other water (such as condensate from inside the space suits) and stored in a reservoir lined with a polymer bladder. Evidently, the ultrapure water leached enough solute (either plasticizer or unreacted monomer) to support the growth of the so-called distilled-water bacteria (e.g., Pseudomonas aeruginosa). These created a nuisance; and since check valves were unreliable in a weightless environment, other potential modes of water contamination 
were envisioned. NASA had commissioned development of an electrolytic silver-ion generator that was intended to decontaminate the water; it was demonstrably capable of generating silver ions in water, but the antimicrobial effectiveness of these ions had not been tested. We were asked to determine the effectiveness of very low silver-ion levels against both distilled-water and pathogenic bacteria, as well as viruses. This required a team, in that we needed help measuring the low levels of silver ions and a more experienced bacteriologist than I. Silver-ion levels in the working range of 50-250 ppb were estimated by a technique called neutron activation analysis (NAA) by Dr. Wesley K. Foell of the UW Department of Nuclear Engineering. Quantification of silver by NAA turned out to be something of an art form; we were not confident enough of the measurements to submit our findings for journal publication. Bacteriological results, reported by Dr. John M. Goepfert of the UW FRI, will not be described here, except to say that substantial kills were obtained at the higher end of the silver-ion working range. Among the viruses tested, only vaccinia appeared to be completely resistant to silver ions. The viruses tested, in order of increasing silver sensitivity, were influenza type A, several enteroviruses, reovirus type 1, and rhinovirus type $1 \mathrm{~A}$. The time dimension for inactivation of these viruses ranged from days to minutes. The rate of inactivation was similar, whether the silver ions had been added by an electrolytic generator or as a soluble salt. The concentration of silver (in the range of 50-250 ppb) was not always the principal rate-limiting factor in inactivation of the virus. We were not able to measure the uptake of silver by the virus particles. Extremely pure water was not necessary for viruses to be inactivated by silver ions. However, feces $(<1 \mathrm{ppm}$, or a dialyzable component of feces) were extremely effective in preventing silver inactivation of enteroviruses and, to a lesser extent, reovirus. Respiratory mucus did not show this sparing effect.

\section{Water and Wastewater}

Environmental virology began with water and wastewater. Although our domain was supposed to be foodborne viruses, there was much to be learned from the study in progress regarding detection and inactivation of viruses in water and wastewater. As mentioned above, we were requested to do some evaluations of a polycation coagulant (Cat-Floc) in controlling viruses in this context. The product showed promise (Cliver 1971); however, our application of the product to extraction of viruses from food samples was probably a mixed blessing to the manufacturer-they wanted to sell their product in large containers, and laboratory applications in food virology mostly produced requests for small volumes.

We were invited to join an interdisciplinary group at UW called the Small Scale Waste Management Program (SSWMP) that was studying on-site wastewater treatment, with a focus on septic tanks and the transport of contaminants through soil in septic tank effluents. We did both model studies of soil transport in laboratory columns (Cliver et al. 1975; Green and Cliver 1975), and transport studies in the field (Alhajjar et al. 1988; Cliver 1984). Field studies were done at homes where SSWMP had already installed groundwater sampling wells, so as to be able to study transport of contaminants from septic tank soil fields (Stramer 1984). Inoculum was obtained by offering unlimited supplies of disposable diapers to mothers whose infants were receiving the oral polio vaccine, if the mothers would freeze and return any diapers with feces in them. Our laboratory thawed and assayed the feces. When at least $100 \mathrm{~g}$ of high-titer feces were accumulated, these were flushed down a toilet at a study-site home, and samples were taken from the septic tank and groundwater over time. The poliovirus tended to accumulate in the sludge in the bottom of the tank, with periodic eruptions that caused the virus to leave the tank with the supernatant and, in time, be detectable in groundwater down-gradient from the soil absorption field. We also studied methods of disinfection for the material that is pumped out of the septic tank at intervals (Stramer and Cliver 1984) and modeled the mixing of human (septic tank effluent) and animal wastes (manure slurry) for disposal to land (Snowdon et al. 1989a, b).

Over time, we had various opportunities to study viral disinfection of urban wastewater effluents; association of viruses with wastewater solids was considered (Cliver 1975). An early project used a mixture of two animal viruses and two bacteriophages to determine how each was inactivated by chlorine dioxide (Olivieri et al. 1983). We worked with Milwaukee, Wisconsin on disinfection of its effluents for discharge to Lake Michigan (Warriner et al. 1985). We helped the Madison (Wisconsin) Metropolitan Sanitary District with a pilot study to show that UV would inactivate viruses in their treated effluent (unpublished) and later worked with them on seasonal antiviral disinfection of their effluent when the full system was in place (Buyong et al. 1993).

We worked with the Committee on the Challenges of Modern Society (the civilian branch of the North Atlantic Treaty Organization) to compile an international review of the microbiology, including virology, of drinking water in industrialized nations (Cliver and Newman 1984). The article, written by 50 scientists in 11 countries, was eventually published as a special edition of a journal (Cliver and Newman 1987). 


\section{Biodegradation}

Early on, I had the idea that, since viruses are not known to autolyze when they lose infectivity, they may be subject to enzymatic or biological degradation in the environment or else they would accumulate at high levels over millennia. Accumulation of vast numbers of viruses in marine water has been reported (Chen et al. 2001), but these are not necessarily agents of human infection, nor are they necessarily infectious as detected. We were able to show that some proteases and some microbes would attack enteroviruses (Cliver and Herrmann 1972); CA9 was especially susceptible to enzyme attack (Herrmann and Cliver 1973a). By differential radionuclide labeling, we demonstrated that CA9 and PO1 in lake water were inactivated by Pseudomonas aeruginosa, which selectively used their coat protein, but not the RNA, as substrate (Herrmann et al. 1974).

Later, as part of the SSWMP program, we were asked to investigate the possibility that septic tank effluent could safely be mixed with animal manure slurry on farms, for eventual disposal to land. After a review of the literature (Snowdon et al. 1989b), we reported some preliminary studies that indicated the manure slurry had some antiviral effect (Snowdon et al. 1989a). More detailed study showed that bacteria from swine manure, as well as in a waste mixture of septic tank effluent and swine manure slurry, were capable of inactivating poliovirus (Deng and Cliver 1992). Further studies showed that bacteria in either dairy or swine manure could inactivate HAV (Deng and Cliver 1995b). Specific bacteria, isolated in pure culture, were shown to attack HAV (Deng and Cliver 1995a); some of the active substances were characterized as specific proteases, but others were of quite low molecular weight and unfortunately were not studied further.

\section{Inactivation}

The hope is that enteric viruses will lose infectivity between when they are shed and when someone else ingests them (Rzezutka and Cook 2004). In addition to the NASA studies described above, we considered foods with a rich bacterial flora that might cause biodegradation of contaminating virus. Lynt had reported that spoilage of several foods held at room temperature had little effect on the persistence of inoculated enteroviruses (Lynt 1966). Because CA9 had been found particularly vulnerable to proteases (Herrmann and Cliver 1973a), it was chosen as the model contaminant in a study of sausage fermentation and of microbial spoilage of ground beef (Herrmann and Cliver 1973b). Although proteolysis (putrefaction) was very evident in the ground beef, less than one $\log$ of inactivation was recorded by 8 days at either 4 or $23^{\circ} \mathrm{C}$; however, substantial reductions were seen at 14 days. Earlier, Kalitina had reported that group B coxsackieviruses persisted equally well in ground beef that had or had not been autoclaved (Kalitina 1966). CA9 was $84 \%$ inactivated during $24 \mathrm{~h}$ of Lactibacillus fermentation at $30^{\circ} \mathrm{C}$ in making Thuringer sausage ( $\mathrm{pH}$ reduced from 6.0 to 4.8 ); subsequent heating of the sausage for $6 \mathrm{~h}$ at $49^{\circ} \mathrm{C}$ left just $0.1 \%$ of the original inoculum infectious (Herrmann and Cliver 1973b). Kalitina had also reported that cottage cheese fermentation did not affect enterovirus persistence (Kalitina 1969). We studied the various stages involved in making cheddar cheese and found that pasteurization of the milk caused a million-fold inactivation of PO1; however that if the virus was added with the starter culture, then there was about $98 \%$ inactivation during cheesemaking and little additional virus loss during 7 months of storage of the product at $4^{\circ} \mathrm{C}$ (Cliver 1973b). Influenza A and vesicular stomatitis viruses, on the other hand, were undetectable in the pressed curd at the end of the cheesemaking process ( $>5-\log$ inactivation).

We undertook to create a mathematical model-outside the context of real foods-of the effects of $\mathrm{pH} 3,5,7,9)$, temperature $\left(2 \& 30^{\circ} \mathrm{C}\right)$, time (days-weeks), and specific salts on the stability of enteroviruses (Salo and Cliver 1976). $\mathrm{PO} 1$ was inactivated faster at any $\mathrm{pH}$ at $30^{\circ} \mathrm{C}$ than at any $\mathrm{pH}$ at $2^{\circ} \mathrm{C}$. At $\mathrm{pH} 3$, glycine-based buffer was somewhat more antiviral than phosphate-based buffer, whereas the reverse was true at $\mathrm{pH} 9 . \mathrm{NaCl}$ and other chloride salts accelerated $\mathrm{PO} 1$ inactivation at $\mathrm{pH} \mathrm{3}$, but $\mathrm{NaCl}$ was much less effective at $\mathrm{pH} 4.5-7$. In this era before the advent of "molecular" techniques, methods of demonstrating virion degradation were relatively unsophisticated. Loss of RNA infectivity appeared to accompany loss of infectivity of the virion, except at $\mathrm{pH} 3$ in the presence of $\mathrm{MgCl}_{2}$. Susceptibility of the virus to RNase or to chymotrypsin was tested with radioactively labeled virus $\left({ }^{32} \mathrm{P}\right.$ in the RNA or ${ }^{14} \mathrm{C}$-leucine in the capsid) and trichloracetic acid (TCA) precipitation. TCA precipitates large molecules nonspecifically; so if the radionuclide of interest was soluble in the presence of TCA, the molecule from which it derived had been degraded. RNA hydrolysis was found to have occurred in PO1 at pH 5 and 7; and the viral RNA became susceptible to RNase in virus inactivated at $\mathrm{pH} 3,5,6$, and 7 . Only virus inactivated at $\mathrm{pH} 3$ became sensitive to chymotrypsin. Echovirus 7 (EC7) has the fortuitous property of agglutinating human $\mathrm{RBC}$ (we used blood group $\mathrm{O}$ ); although this may have nothing to do with infectivity, it seems similar to the blood group antigen affinities of norovirus (Marionneau et al. 2002). The hemagglutinins of

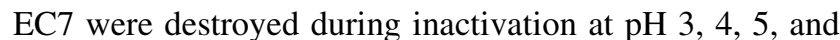
6; loss of hemagglutinin seemed precede loss of infectivity at pH 6 (Salo and Cliver 1976). 
Additional methods of characterizing modes of virus inactivation were applied in studies of inactivation of CA9, EC7, and PO1 by ascorbic acid and sodium bisulfite $\left(\mathrm{NaHSO}_{3}\right)$ (Salo and Cliver 1978). These studies had been prompted by Lynt's perception that sodium bisulfite in cole slaw had antiviral activity (Lynt 1966). All the three viruses were susceptible to these food additives at levels of $0.1 \mathrm{M}$ and sometimes much less (Salo and Cliver 1978). Methods of characterizing virus degradation during inactivation included: loss of hemagglutinating activity (EC7 only); differential adsorption to cellulose nitrate (Millipore GSWP) and cellulose acetate (Gelman GA-8) filters; differential attachment to primate (HeLa) and non-primate (MDBK-bovine) cells; RNA infectivity of whole virus or cold phenol-extracted RNA as facilitated by DEAE-dextran; and sedimentation in sucrose density gradients. When whole virus was apparently inactivated, in that it could no longer initiate plaques, it was often infectious when inoculated together with DEAE-dextran, which showed that the viral RNA was intact. The native viruses were adsorbed by cellulose nitrate but not cellulose acetate filters, as reported previously (Herrmann and Cliver 1973c); however, PO1 labeled with ${ }^{32} \mathrm{P}-\mathrm{RNA}$ and inactivated by $25 \mathrm{mM} \mathrm{NaHSO}$ gradually developed affinity for the cellulose acetate membrane, as measured by retention of virus-associated radionuclide. ${ }^{14} \mathrm{C}$-leucine labeled PO1 showed low nonspecific attachment for MDBK (bovine) cells: after inactivation, the virus had no more affinity for HeLa (human) cells than for MDBK. Much ${ }^{32} \mathrm{P}$ in $\mathrm{PO} 1$ inactivated by ascorbate no longer banded as native virus fraction in the sucrose density-gradient experiments; in one instance, EC7 (which has the same sedimentation profile) was mixed with the PO1 before centrifugation. EC7 hemagglutination identified the fractions that would contain native PO1. Some of these means of characterizing inactivated virus might be adaptable for use with molecular methods.

Konowalchuk and Speirs had reported that viruses were inactivated in vitro by a variety of fruits and fruit juices (Konowalchuk and Speirs 1976a, b; Konowalchuk and Speirs 1978 a, b). Inactivation by apple juice was said to be irreversible (Konowalchuk and Speirs 1978a). We focused on the effects of Concord grape juice, which inactivated CB3, EC6, and PO1 but not parainfluenza virus type 3 (Cliver and Kostenbader 1979). Filtration of ${ }^{32}$ P-labeled, inactivated PO1 through a $50-\mathrm{nm}$ porosity polycarbonate membrane ruled out aggregation as a cause of titer loss. The inactivated virus showed limited attachment to homologous host cells but did not infect them. Treatment with polyethylene glycol (m.w. 20,000) reactivated the inactivated virus, as did human blood serum, indicating that the capsid had not been permanently modified. We had fed infant pigs human foods in an effort to make their GI tracts as nearly analogous to humans' as possible. We collected contents of stomach, duodenum, jejunum, ileum, cecum, and descending colon, and reacted these with grape-juice inactivated PO1 for $30 \mathrm{~min}$ at room temperature; the treated virus was reactivated $42-82 \%$, depending on which GI contents were used. In addition to native virus, we used coproantibody-neutralized PO1 as a control; reactivation occurred with stomach, duodenum, and cecum contents, but not the material from other segments of the GI tract. It is unfortunate that the apparent reactivation of coproantibody-neutralized virus, which would have occurred upon ingestion, was not given more weight (not mentioned in the title, and only briefly in the abstract), as this finding may well have had greater public-health significance than the grape-juice results.

Enteroviruses attracted attention to coproantibody (presumably IgA) because they are shed for prolonged periods (often weeks) and are neutralized by coproantibody during the later part of the shedding period. Our first interest had been in how coproantibody might interfere with virus detection in cell cultures; the study just described was perhaps the first to show that coproantibody-neutralized virus is quite likely infectious if ingested. After extraction from potato salad by our early Freon method, PO2 was completely reactivated if it had been neutralized with coproantibody, but it was only partly reactivated if neutralized with hyperimmune rabbit serum (presumably IgG) (Herrmann and Cliver 1968b). Some laboratories have been reluctant to use Freon, for various reasons. We later showed that coproantibody-neutralized PO1 extracted from ground beef could be reactivated by treatment with pancreatin (an extract of bovine pancreas containing a variety of proteases and other enzymes); the resulting extract could be tested as much as $35 \mathrm{ml}$ per $25-\mathrm{cm}^{2}$ cell culture, and could be passed among different types of cell cultures, to detect cytopathic viruses (Kostenbader and Cliver 1986).

We participated in a cooperative study on $\mathrm{ClO}_{2}$ inactivation of enteric viruses in water mentioned earlier (Olivieri et al. 1983). The primary target was PO1; but we included a porcine enterovirus, an RNA bacteriophage (f2), and a DNA bacteriophage ( $\phi$ X174). Because these had mutually exclusive host ranges, all the four were included in the reaction mixture and assayed individually in the samples. Most similar to the PO1 in inactivation was the $\phi X 174$; least similar to the PO1 was the porcine enterovirus, which proved much more sensitive than any of the other three to $\mathrm{ClO}_{2}$ : see Surrogates, next section. RNA infectivity of the PO1 was apparently little affected by $\mathrm{ClO}_{2}$. HAV in tap water and in strawberry wash water was inactivated by $\mathrm{ClO}_{2}$ at $4 \mathrm{ppm} ; \mathrm{ClO}_{2}$ was less efficient at inactivating $\mathrm{HAV}$ in experimentally contaminated strawberries, which were better disinfected by heat treatment $\left(71.7^{\circ} \mathrm{C}, 60 \mathrm{~min}\right)$ after the strawberries had been made into puree (Mariam and Cliver 2000a). 
The two principal legal pasteurization methods for milk in the USA are the low-temperature, long-time method (LTLT: $63^{\circ} \mathrm{C}, 30 \mathrm{~min}$ ) and the more common high-temperature, short-time method (HTST: $72^{\circ} \mathrm{C}, 15 \mathrm{~s}$ ). We found that HAV was somewhat more susceptible to LTLT pasteurization than to HTST pasteurization in both homogenized, pasteurized whole milk and in raw whole milk. Inactivation was $94 \%$ by LTLT and $27 \%$ by HTST in raw milk (Mariam and Cliver 2000b). This study was inspired by an earlier Michigan outbreak of HA in a religious group that did not use electricity or machinery. They milked their cows by hand (with highly inadequate hand-washing facilities) and sold it to a neighboring cheese plant; these data indicated that the cheese produced after the milk was pasteurized would not have been safe, in contrast to our earlier result with poliovirus (Cliver 1973b).

RT-PCR was known to detect inactivated viruses in water and wastewater (Sobsey et al. 1998); the same was likely to be true for inactivated viruses in food. We found that a combination of proteinase $\mathrm{K}$ and RNase would eliminate most false-positive RT-PCR results with feline calicivirus (FCV - at that time, the best available surrogate for human norovirus), $\mathrm{HAV}$, and PO1 inactivated by chlorine, heat $\left(72^{\circ} \mathrm{C}\right)$, and UV (Nuanualsuwan and Cliver 2002). The treatment did not prevent RT-PCR detection of viruses inactivated at $37^{\circ} \mathrm{C}$ over long periods of time, as might occur in the environment; although the capsid protected the RNA, it was unable to attach to host cell receptors (Nuanualsuwan and Cliver 2003a). We compared the infectivity of RNA in PO1 inactivated by chlorine, heat, and UV and found that the rates of inactivation for RNA and whole virus were similar with chlorine and UV inactivation but that RNA infectivity persisted during inactivation at $72^{\circ} \mathrm{C}$ (Nuanualsuwan and Cliver 2003b). Several laboratories are now studying other methods to reduce false RT-PCR positive results with inactivated virus (Rodriguez et al. 2009).

\section{Surrogates}

Presently, model agents such as murine norovirus are being used experimentally to predict the persistence of human noroviruses in food and the environment, in that cultivation of human noroviruses in laboratory cell cultures has not lent itself to such experiments (Duizer et al. 2004). However, the challenges of detecting viruses in food and water, even when host systems were available, have always evoked wishes that surrogates could be found that would obviate testing field samples for the presence of viruses themselves. Both bacterial "indicators" and other viruses, including bacteriophages, have been considered. I will not try to survey the vast literature on this subject, but only give an overview of our activities. In that we were in a landlocked location, we welcomed the opportunity to join a collaboration looking at bacterial indicators and Gulf Coast oysters (Fugate et al. 1975). EC6, PO1, and poliovirus 3 were found in the oysters, with no apparent correlation with coliform MPN, E. coli MPN, aerobic plate count, or the presence of Pseudomonas aeruginosa.

Concern about viral contamination of groundwater by on-site wastewater treatment systems led to consideration of coliphages as indicators (Johnson and Cliver 1986; Snowdon and Cliver 1989). In field studies with poliovirus introduced to groundwater via septic tanks, indicator bacteria (total coliforms, fecal coliforms, fecal streptococci) were not consistently present in groundwater samples in which the virus occurred (Alhajjar et al. 1988; Stramer 1984). Since human viruses cannot multiply in the environment, it was important to show that candidate indicator coliphages could not multiply in the environment, either. We focused on FRNA ("male-specific") coliphages, which are similar in size to the small enteric viruses and were detected in about half of septic tanks from various areas of Wisconsin (Woody and Cliver 1994). These were not found in groundwater samples, even if taken directly under the soil infiltration field. Phage $\mathrm{Q} \beta$ was used as a model: it was found that F-pilus synthesis by host cells did not occur at temperatures below $25^{\circ} \mathrm{C}$-a temperature not encountered in Wisconsin groundwater nor in many Wisconsin surface waters (Woody and Cliver 1995). Also, the host $E$. coli cells had to be actively growing (log phase) to support $\mathrm{Q} \beta$ replication, which is less likely in the environment than in permissive conditions in the laboratory. Other constraints that were identified included competition from insusceptible bacteria with the host cells, which needed to be present at at least $10^{4} \mathrm{CFU} / \mathrm{ml}$ to support $\mathrm{Q} \beta$ replication, competition from other phages, lack of nutrients in environmental waters, etc. (Woody and Cliver 1997). We did describe a convenient viradel method for detecting waterborne coliphages (Jothikumar and Cliver 1997), and a fluorescent plaque assay for coliphages from environmental samples (Jothikumar and Cliver 1998).

The comparative study of $\mathrm{ClO}_{2}$ disinfection was discussed in the previous section; the similarity of inactivation of PO1 and $\phi \mathrm{X} 174$ was apparently fortuitous, in that the porcine enterovirus, which resembled PO1 biologically, lost infectivity much more rapidly than PO1 and either bacteriophage (Olivieri et al. 1983). We compared an FRNA coliphage (MS2) and a small DNA coliphage ( $\phi \mathrm{X} 174)$ with HAV under various conditions of inactivation: MS2 inactivation was fairly similar to that of HAV during heating in water and milk, especially at $72^{\circ} \mathrm{C}$ (Mariam and Cliver 2000b). Both phages were more susceptible than HAV to drying and to $\mathrm{ClO}_{2}$ disinfection. A UV disinfection study yielded decimal inactivation doses for FCV, HAV, PO1, 
MS2, and $\phi X 174$ of $47.85,36.50,24.10,23.04$, and $15.48 \mathrm{~mW} \mathrm{~s} / \mathrm{cm}^{2}$, respectively (Nuanualsuwan et al. 2002).

\section{"Practical" Studies}

The majority of our virology studies, especially with food, were necessarily performed in the laboratory. All the same, there was a constant urge to look for viruses in the real world of the food chain. The FRI was sponsored by many major food companies, and so it seemed reasonable to approach them first for permission to enter and sample. Few were willing, and many constraints came with the permissions we did receive. Seven plants were eventually sampled, each processing a different group of foods (Kostenbader and Cliver 1977). In order to deal with this diversity, we developed a sampling plan that was adaptable to all. In order to monitor inputs, we chose to sample: (1) raw materials, (2) water used in processing, and (3) plant personnel. Outputs of the following types were sampled: (1) finished product, (2) by-products, (3) wastes, (4) plant personnel, and (5) wastewater. All the samples were to be tested for ability to produce CPE or plaques in cell cultures. Because of the diversity of samples in prospect, the following types of cell cultures were used as appropriate: primary monkey (Macaca mulatta) kidney, primary swine embryo kidney, chicken embryo fibroblast, HeLa, Vero (Cercopithecus aethiops), and Madin-Darby bovine kidney. Two methods mentioned earlier were quantitatively validated: one entailed inoculation of as much as $1.4 \mathrm{ml}$ of sample per square centimeter of cell monolayer, with subsequent observation for CPE; the second involved testing the same sample in more than one type of cell culture by incubating the inoculum in the first culture for $20 \mathrm{~h}$ at $37^{\circ} \mathrm{C}$ and then transferring the inoculum to another type of cell culture. Both practices were shown to result in minimal loss of viral infectivity, even when the first inoculated culture was an insusceptible cell type, sometimes infected with a competing virus. Processing methods for diverse samples were also validated.

Plant A manufactured groceries. Samples tested included isomerose, gelatin, well water, wastewater, cheesecake mix, breakfast drink mix, freezer "pops," and strawberry preserves; no virus was detected.

Plant $B$ dried potatoes. Samples tested included raw well water; whole raw potatoes; stool samples from four workers who handled raw potatoes; dried potato granules, flakes, and slices; wastewater sludge from primary and secondary treatment; mud washed from the potatoes; floor sweepings; and stool samples from three workers who handled final product. No virus was detected.
Plant $C$ slaughtered and processed swine. Samples tested with negative results included swine blood, raw well water, wastewater from sewer lines serving a spice-kitchen workers' locker room and a kill-floor workers' locker room, supernatant fluid from process wastewater, and packaged luncheon meat. The rate of intestinal infection of animals at the time of slaughter was found to be quite high. All the 10 fecal samples taken from holding pen floors on Monday, when the animals had been together for three days were positive. Three of these viruses were identified as reoviruses and the remaining seven were enteroviruses, of which six replicated only in swine cells, but one also replicated in monkey cells. A small, heat-stable agent that could not be sustained beyond two passages in swine cells was detected in sediment from process wastewater, in de-watered primary sludge, and in raw and cooked meat scraps. Follow-up sampling of swine feces and intestinal contents at the plant revealed a high incidence of enteroviruses, some of which replicated only in swine cells, while others replicated in both swine and monkey cells.

Plant $D$ shelled eggs and froze liquid egg products. Negative test results were obtained from all the samples: eggs in the shell, washings from the shells, liquid whole eggs, liquid egg whites, "leakers," spent shells, and process wastewater.

Plant E slaughtered cattle and swine. Samples taken there-contents of cattle and swine large intestines, swine blood, bologna, raw beef scraps, raw pork scraps, cooked mixed scraps, dried mixed scraps, and samples from the combined process wastewater and sanitary sewage treatment system (raw, digested, and dried sludge and aerated effluent)-failed to reveal virus. This plant was more than 1000 miles $(\sim 1600 \mathrm{~km})$ from plant $\mathrm{C}$, and climatic conditions were very different.

Plant $F$ produced frozen ground beef patties from chunks of boned beef. Final product from three different days' operations was tested. Extracts of one of these samples repeatedly produced CPE in bovine cell cultures, but was not characterized because it could not be carried beyond the second passage.

Plant $G$ slaughtered and processed chickens. Samples of chicken blood and intestines, raw well water, diced chicken meat, plant solid waste, and wastewater from the sanitary sewer line gave negative test results.

We did a second sampling series that was directed especially to food processing personnel in Plant $\mathrm{C}$ and eight other establishments. Samples were collected from the sanitary sewer lines that served personnel toilets, either as grab samples or with swabs suspended in the line for a week. None of these was shown to contain the virus.

We also tested 10 retail samples of each of six foods from a total of five different stores. Samples included ground beef, luncheon meat, lettuce, poultry pot pies, 
delicatessen salads, and tomatoes. Many of these food samples were tested repeatedly, but no virus was found.

Of the viruses that we were capable of detecting at that time, none was found that was of apparently human origin, either in the processing facilities or the final products. The swine viruses detected in plant $\mathrm{C}$ were probably of no significance to human health (Kostenbader and Cliver 1977).

One other "practical" study will be described here (Cliver and Kostenbader 1984). The topic was disinfection of fingers contaminated with virus in feces. Many such studies have since been done (Ansari et al. 1988, 1989; Bidawid et al. 2000, 2004; Mbithi et al. 1992, 1993; Sattar and Ansari 2002). Our study was distinguished by the use of virus shed in feces in the course of infection, inclusion of a number of brand-name disinfectants, application of glass coverslips as a receiving surface, and evaluation of disposable plastic gloves as a virus barrier. Some of the fecal material came from pigs infected with a swine enterovirus; other samples came from a child shedding poliovirus after oral vaccination; all were frozen at $-20^{\circ} \mathrm{C}$ until used experimentally. Fingers (principally those of the present author) of hands that had been thoroughly washed with soap and water were pressed lightly onto the fecal surface and, in baseline studies, touched to sterile glass coverslips. This permitted precise gravimetric determination of the quantity of fecal material deposited; food surfaces, faucet handles, bar soap, towels, etc. were also touched, but the feces were ultimately deposited on coverslips to allow quantification. Some of the experiments were performed on shaved swine skin as well. When the virus was recovered from the coverslip and assayed by the plaque technique, the weight determination enabled estimation of how much virus had been removed by cleansing and how much had probably been inactivated. A highly alkaline $(\mathrm{pH}$ 8.8) hand soap was found to be strongly antiviral, and a comparable alkaline buffer was found to be equally effective. In general, disinfectants that were well tolerated by human skin were relatively ineffective. Disposable plastic gloves were shown both to prevent contamination of clean fingers touching virus-containing feces and to prevent contamination of other surfaces contacted by fecally contaminated fingers.

\section{Peroral and Ex-Vivo Infectivity}

Cell cultures provided a powerful tool for food and environmental virology, as well as many other aspects of virology. Still, questions continued to arise that could not be answered by cell-culture experiments alone. Two that we undertook to address were: (1) How much virus comprises a peroral infectious dose? (2) What happens when ingested virus encounters receptors in the intestinal mucosa?

Peroral infectivity trials had been done with human volunteers (Gary et al. 1987; Grohmann et al. 1981; Schiff et al. 1984), but we felt that they included too many uncontrolled variables. With support (1975-1978) from the US EPA, we undertook peroral infectivity studies using young swine as experimental subjects. The Abstract of the final report to EPA (Cliver 1980) says:

"This study was designed to examine the relationship of waterborne enteroviruses to infections and disease. Young weanling swine and their homologous enteroviruses were chosen as the model system: The porcine digestive tract is like that of man, but pigs can be handled under more closely standardized conditions than humans or other primates. Porcine enteroviruses resemble those of man in every way, but they infect swine so specifically that handling the most virulent of the porcine agents is apparently no threat to the health of research personnel. Known quantities (as measured by the plaque technique in tissue cultures) of two enteroviruses were administered in $5 \mathrm{ml}$ of drinking water in such a way that the subjects were obliged to swallow all of it. The host's body was found to be about 1000 times (600-750 for one virus and 1800-2500 for the other) less likely than the tissue cultures to be infected by a given quantity of enterovirus. The ratio did not depend on whether the animals were fed just before challenge. The probability of infection was cumulative with iterated small doses: this indicated that there was, in the strict sense, no minimum infectious dose. None of the infected animals became ill, despite the reported virulence of the challenge viruses. Chlorine treatment of a concentrated virus suspension, which reduced infectivity to a level detectable by cytopathic effect but not plaque formation in tissue culture, left enough virus to infect one of five challenged subjects. Neither of two colostrum-deprived pigs, challenged by stomach tube with 20 plaque-forming units of enterovirus at $1 \frac{1}{2} \mathrm{~h}$ of age, became infected."

Inevitably, there were complications: groups of 10 pigs were purchased from University and commercial swine farms and left with their dams for 2-8 days to ensure that they got as much passive immunity from colostrum as possible. Then they were moved to a "fostering unit," developed by the UW Department of Meat and Animal Science, in the FRI animal quarters. This was a box, inside of which were a slanted false floor, thermostatically controlled ventilation system, and dispensing troughs for milk replacer; observation and access were permitted by hinged acrylic panels at the top. The principal purpose of the fostering unit was removing the pigs from potential sources of enterovirus infection long enough to complete testing of the initial fecal specimens before the animals were put into isolators. Even with the colostrum for passive immunity 
and various other precautions, diarrheal illness occurred frequently, and it was not always possible to keep the pigs healthy and normal (or at times, even alive) to the age of $3 \frac{1}{2}$ weeks. At approximately $3 \frac{1}{2}$ weeks, assuming the animals were healthy and had been found not to harbor adventitious enteroviruses, eight of them were moved to individual isolators. Any remaining pigs became donors for kidney cell cultures. The isolators had acrylic fronts and HEPA-filtered air supplies, to preclude non-experimental sources of infection. The animals were fed two meals per day of food produced for human consumption, plus water ad lib. Feeding and watering, as well as emptying the litter trays from beneath the false floors, were done with aseptic precautions. Cages were entered in numerical order, and the pig in cage 8 always served as an unchallenged control. Despite our precautions, on three occasions, 14-day fecal specimens were positive from pigs that had not been challenged, though never from the pig in cage 8 . Since the corresponding 7-day specimens had been negative, we surmised that the pigs had become infected while in the isolators, but were never able to determine how this could have happened. In addition to these technical challenges, we learned that well-fed pigs quickly become large and intractable. All suspect results were discarded, and a succinct report of the research was published in the Journal of Food Protection (Cliver 1981). This was a one-of-a-kind study; we believe that the results (particularly regarding split doses) are significant to the question of peroral infectivity of viruses.

Another study to be described here addressed what I chose to call "ex-vivo infectivity." We undertook to maintain explants of intestinal mucosa in their native functional state outside the donor's body, so as to observe early events in enterovirus infection. A number of such studies had been done before ours, using explant cultures from swine, cattle, feline, and human fetal intestines (Bridger et al. 1978; Derbyshire and Collins 1971; Dolin et al. 1971, 1972; Hoshino and Scott 1980; Rubenstein and Tyrrell 1970; Rubenstein et al. 1970; Wyatt et al. 1973); we hoped to develop additional, useful information. Our first experiments were done with $2-3-\mathrm{mm}$ square explants from the distal ileums of $22-30-\mathrm{cm}$ fetal pigs (Jensen and Cliver 1984). Five areas per Petri plate had been scratched to facilitate attachment; the prepared explants were placed mucosal-side-up in these areas and incubated at $37^{\circ} \mathrm{C}$ with MEM plus fetal calf serum and antibiotics. Porcine enterovirus 3 had been photosensitized by replication in the presence of neutral red (Wilson and Cooper 1965): a strong pulse of visible light from a fluorescent lamp reduced the titer by 5 logs. The virus and the explants were held in the dark and handled by the light of a photographer's red safe light. A dissecting microscope showed apparently normal villous structure during the first 4 days, with significant deterioration thereafter; net yields of light-resistant progeny virus ranged from 1 to $3 \operatorname{logs}$ by day 2 or 4 .

In a later study, we paid closer attention to maintaining normal organization of the villous mucosa (Heinz et al. 1987). Intestinal tissue was collected from female Yorkshire pigs, either 4-6 weeks or 9-11 months old and prepared in $4-\mathrm{cm}^{2}$ explants; histology was monitored by light microscopy and scanning and transmission electron microscopy. Comparison of various medium formulations led to the selection of CMRL-1066, supplemented with insulin and cortisone, which would maintain apparently normal villous organization for $48 \mathrm{~h}$. Explants were inoculated with either coxsackievirus B5 (CB5), which is infectious for swine, or with PO1, which is not. Only $24 \mathrm{~h}$ at $37^{\circ} \mathrm{C}$ were allowed, to ensure that the explants were as normal as they looked. Retention and replication of the two viruses were compared in explants of absorptive and lymphoid mucosa from young and adult animals. Retention was limited, but favored CB5 in all cases and was greater in absorptive tissue than in lymphoid tissue; age differences were minimal. Replication of CB5 was also limited, but statistically significant and greatest in absorptive tissue from young animals and least in lymphoid tissue from young animals; yields from adult absorptive and lymphoid tissue were intermediate between these and approximately equal. We then focused more closely on the earliest interactions between these viruses and explants (Heinz and Cliver 1988). Tritiated CB5 and PO1 were incubated with explants for $6 \mathrm{~h}$ at $6^{\circ} \mathrm{C}$ to measure and attachment or $1 \mathrm{~h}$ at $37^{\circ} \mathrm{C}$ to measure penetration, followed by liquid scintillation counting and autoradiography. Results at $6^{\circ} \mathrm{C}$ were anomalous, suggesting that this was not a valid temperature for measuring virus attachment to explant cultures. Retention at $37^{\circ} \mathrm{C}$ was apparently greater in adult absorptive and lymphoid tissue, but more specific in young lymphoid tissue, where the ratio of CB5:PO1 was 4.3. It was seen that only a small proportion of CB5 associated with the explants, and penetration was principally into the epithelial cells along the upper third of the villi (those at or approaching senescence) and/or the lamina propria. Virus that associated with enterocytes further down the villi or in the crypts apparently did not penetrate the cells. It seemed that, since the enterocytes into which the virus penetrated were nearing the end of their functional lives, this might to some extent explain the typical absence of diarrhea in enterovirus infections. The findings might be quite different if the experimental system comprised porcine ileal explants inoculated with porcine norovirus. 


\section{Detection Without Cell Culture}

Though most of our studies since 1962 were directed to getting viruses out of environmental samples and into cell cultures for detection, it became clear that cell cultures were not the only means of virus detection and, in some instances, were of no use whatever in this application. A number of virus-detection methods based on enzymelinked immunosorbent assay (ELISA) had been described by 1980 for use in rapid clinical diagnosis (Deng and Cliver 1984). Each of these used selected antibodies for individual viruses. In that pooled human immune serum globulin (HISG) contains antibodies reflecting the combined immunologic experience of the donor population, we considered how HISG might be used in a broad-spectrum virus detection method. Five human enteroviruses, reovirus 1 , and two porcine enteroviruses were selected for testing by a method modified from that of Herrmann et al. (Herrmann et al. 1979). Wells in a 96-well, polystyrene microtiter plate were pre-coated with poly-L-lysine. Virus suspensions (various concentrations) were incubated at $4{ }^{\circ} \mathrm{C}$ for 20-24 h in these wells, after which the wells were washed with PBS + Tween-20 and bovine serum albumin. HISG that had been absorbed with host cell antigens was added to the wells and incubated for $30 \mathrm{~min}$ at $37^{\circ} \mathrm{C}$, after which the wells were washed again. Goat anti-human $\mathrm{IgG}$ labeled with peroxidase was incubated in each well for $2 \mathrm{~h}$ at $37^{\circ} \mathrm{C}$, and the wells were washed again and reacted with 2,2'-azino-di-3-ethyl-benzthiazoline-6-sulfonate-hydrogen peroxide substrate for $20 \mathrm{~min}$ at room temperature and stopped with hydrofluoric acid. Optical densities were read at $410 \mathrm{~nm}$ in a microplate reader. With a positive:negative ratio of 2 as the cut-off, the human enteroviruses and reovirus were detected at levels of $10^{4}-10^{6}$ infectious units (PFU or MPNCU) per well; no signal was obtained with the porcine enteroviruses. In that the reaction was not typespecific, positive signals from two different viruses in the same well augmented each other. We did not pursue this method further because of its limited sensitivity, but there might well be ways of applying HISG for broad-spectrum immunomagnetic capture before RT-PCR testing.

After the FRI installed a PCR facility, we did apply antigen capture in tubes for RT-PCR detection of HAV in various inoculated wastewaters and in ${ }^{60} \mathrm{Co}$-irradiated oysters and clams (Deng et al. 1994) and then immunomagnetic capture for HAV detection in oysters (LópezSabater et al. 1997). We were obliged to install our own, much less elegant PCR facility after moving to UCD. HAV inoculated into water and sewage samples was concentrated by the viradel procedure (elution with urea-arginine phosphate buffer), concentrated specifically by immunomagnetic capture, and detected by RT-PCR (Jothikumar et al. 1998).
Later, we took up the issue (discussed earlier) of detection by RT-PCR of inactivated virus. Although our work yielded only a partial solution (Nuanualsuwan and Cliver 2002; Nuanualsuwan et al. 2002), the study has been taken up by others and progress will surely be made. We were able to characterize some of the changes in the virion that occurred with inactivation, in the hope that this information may point to further modes of attack (Nuanualsuwan and Cliver 2003a, b).

A further confounding factor is that the number of viral particles and of genomes detectable by RT-PCR greatly exceeds the number of infectious units measured by plaque formation or cytopathology $\left(\mathrm{TCD}_{50}\right.$ or MPNCU). Isolation of more than one type of poliovirus from a plaque in a culture that received mixed inoculum has been reported by Teunis et al. (2005), but this represents a relatively small potential disparity compared to the numbers of virions often shown to be present in a suspension. Direct particle counts by scanning electron microscopy gave mean particle:PFU ratios of 448 for a vaccine strain of PO1, and 38 for an ostensibly virulent strain of CB5 (Heinz et al. 1986). In an antigen-capture RT-PCR study, a cDNA-RNA technique yielded an estimate of 79 HAV particles:PFU; the estimated limit of detection was $0.053 \mathrm{PFU}$, the equivalent of four particles (Deng et al. 1994). These degenerate ratios are more likely the result of inefficiency in the initiation of infection at the cell level than of a large proportion of defective or noninfectious virions.

\section{Prions}

Surely, one of the most fascinating events in our field has been the demonstration of prion diseases (transmissible spongiform encephalopathies) as an international threat to human health. Our group had no prospect of acquiring the safety facilities required to work with these agents, but I did have the good fortune to serve on the US Food and Drug Administration Transmissible Spongiform Encephalopathies Advisory Committee from 1998 to 2002. We advised about regulatory approaches to preventing prion-disease transmission, particularly in the context of human healthcare (e.g., blood transfusion and blood product processing and distribution). I also served on the National Academies Institute of Medicine, Committee on Transmissible Spongiform Encephalopathies: Assessment of Relevant Science during 2002 and 2003; we developed a book-length set of recommendations for future TSE research in the USA (Erdtmann and Sivitz 2004)_its effects on the course of public health research are uncertain.

At least some of the regulatory approaches to excluding bovine spongiform encephalopathy from transmission via food to humans were predicated on detecting prohibited 
bovine tissues in animal-origin foodstuffs. We were able to contribute to the selection of detection methods (Hajmeer et al. 2003) and their application to "advanced meat recovery" products (Hajmeer et al. 2006). The methods used immunological procedures to detect banned tissue: the latter was a method for detecting abnormal prions, minus the proteinase $\mathrm{K}$ that would remove normal prions from the sample.

\section{Conclusion}

The years from 1962 to 2007, when I retired, witnessed enormous progress in the field of food and environmental virology: I never thought there would be a journal devoted to this field. My group made several contributions, though much of the time we were handicapped by severe lack of funding. A presentation I gave some years ago was entitled, "Viruses around Us, or How We Are Identifying and Solving the World's Environmental Virology Problems on Practically No Money at All." This must have been due partly to my lack of salesmanship, in that most granting agencies, most of the time, did not regard foodborne and waterborne viruses as a major threat to human health. Some other university researchers did better than I. Intramural research was sustained by EPA and less so (over time) by FDA. The Canadian government had an on-andoff virology program: when their virologists were in a hiatus, they discovered that the shiga-like toxin of $E$. coli was toxic to the Vero cells they had been using in virus research (Konowalchuk et al. 1977; Speirs et al. 1977). We studied other topics at times, as well, and some of the virology studies were abandoned before reaching maturity. I wish we had accomplished more and trained more students, but we did what we could and enjoyed almost every minute of it. I wish those who are now carrying on the research as much pleasure as I have had from it.

Open Access This article is distributed under the terms of the Creative Commons Attribution Noncommercial License which permits any noncommercial use, distribution, and reproduction in any medium, provided the original author(s) and source are credited.

\section{References}

Alhajjar, B. J., Stramer, S. L., Cliver, D. O., \& Harkin, J. M. (1988). Transport modelling of biological tracers from septic systems. Water Research, 22, 907-915.

Ansari, S. A., Sattar, S. A., Springthorpe, V. S., Wells, G. A., \& Tostowaryk, W. (1988). Rotavirus survival on human hands and transfer of infectious virus to animate and nonporous inanimate surfaces. Journal of Clinical Microbiology, 26, 1513-1518.

Ansari, S. A., Sattar, S. A., Springthorpe, V. S., Wells, G. A., \& Tostowaryk, W. (1989). In vivo protocol for testing efficacy of hand-washing agents against viruses and bacteria: Experiments with rotavirus and Escherichia coli. Applied and Environmental Microbiology, 55, 3113-3118.

Atmar, R. L., Neill, F. H., Romalde, J. L., Guyader, F. L., Woodley, C. M., Metcalf, T. G., et al. (1995). Detection of Norwalk virus and hepatitis A virus in shellfish tissues with the PCR. Applied and Environmental Microbiology, 61, 3014-3018.

Atmar, R. L., Neill, F. H., Woodley, C. M., Manger, R., Fout, G. S., Burkhardt, W., et al. (1996). Collaborative evaluation of a method for the detection of Norwalk virus in shellfish tissues by PCR. Applied and Environmental Microbiology, 62, 254-258.

Berg, G. (1967). Transmission of viruses by the water route. New York: Interscience (John Wiley \& Sons).

Berg, G., Clark, R. M., Berman, D. A., \& Chang, S. L. (1967). Aberrations in survival curves. In G. Berg (Ed.), Transmission of virus by the water route (pp. 235-240). New York: Interscience.

Bidawid, S., Farber, J. M., \& Sattar, S. A. (2000). Contamination of foods by food handlers: Experiments on hepatitis A virus transfer to food and its interruption. Applied and Environmental Microbiology, 66, 2759-2763.

Bidawid, S., Malik, N., Adegbunrin, O., Sattar, S. A., \& Farber, J. M. (2004). Norovirus cross-contamination during food handling and interruption of virus transfer by hand antisepsis: Experiments with feline calicivirus as a surrogate. Journal of Food Protection, 67, 103-109.

Bridger, J. C., Caul, E. O., \& Egglestone, S. I. (1978). Replication of an enteric bovine coronavirus in intestinal organ cultures. Archives of Virology, 57, 43-51.

Buyong, N., Cliver, D. O., Ronner, A. B., \& Kostenbader, K. D. (1993). Seasonal UV disinfection of treated urban effluent. 2. Virological findings. Journal of Environmental Science and Health. Part A. Environmental Science Engineering A, 28, 2299-2314.

Chang, S. L. (1967). Statistics of the infective units of animal virus. In G. Berg (Ed.), Transmission of viruses by the water route (pp. 219-234). New York: Interscience.

Chen, F., Lu, J. R., Binder, B. J., Liu, Y. C., \& Hodson, R. E. (2001). Application of digital image analysis and flow cytometry to enumerate marine viruses stained with SYBR gold. Applied and Environmental Microbiology, 67, 539-545.

Cliver, D. O. (1965a). Factors in the membrane filtration of enteroviruses. Applied Microbiology, 13, 417-425.

Cliver, D. O. (1965b). Viruses and rickettsia in foods and the possible role of radiation preservation. In Radiation preservation of foods (pp. 269-272). Washington, DC: National Academy of Sciences, National Research Council.

Cliver, D. O. (1966). Implications of food-borne infectious hepatitis. Public Health Reports, 81, 159-165.

Cliver, D. O. (1967a). Detection of enteric viruses by concentration with polyethylene glycol. In G. Berg (Ed.), Transmission of viruses by the water route (pp. 109-120). New York: Interscience.

Cliver, D. O. (1967b). Enterovirus detection by membrane chromatography. In G. Berg (Ed.), Transmission of viruses by the water route (pp. 139-141). New York: Interscience.

Cliver, D. O. (1967c). Food-associated viruses. Health Laboratory Science, 4, 213-221.

Cliver, D. O. (1968). Apparent "double mutation" induced by gamma rays. Nature, $218,187-188$.

Cliver, D. O. (1969). Viral infections. In H. Riemann (Ed.), Foodborne infections and intoxications (1st ed., pp. 73-113). New York: Academic Press.

Cliver, D. O. (1971). Viruses in water and wastewater: Effects of some treatment methods. In V. Snoeyink \& V. Griffin (Eds.), Virus and water quality: Occurrence and control. Proceedings of the thirteenth water quality conference (pp. 149-158). Urbana, IL: Engineering Publications Office, University of Illinois-Urbana. 
Cliver, D. O. (1973a). Apparatus for changing tissue culture media. In P. F. J. Kruse \& M. K. J. Patterson (Eds.), Tissue culture: Methods and applications (pp. 224-226). New York: Academic Press.

Cliver, D. O. (1973b). Cheddar cheese as a vehicle for viruses. Journal of Dairy Science, 56, 1329-1331.

Cliver, D. O. (1975). Virus association with wastewater solids. Environmental Letters, 10, 215-223.

Cliver, D. O. (1976). Food borne viruses. In M. Speck (Ed.), Compendium of methods for the microbiological examination of foods (1st ed., pp. 462-470). Washington, DC: American Public Health Association.

Cliver, D. O. (1980). Infectivity and pathogenicity of enteroviruses ingested with drinking water. EPA 600/1 80 005. Cincinnati, OH: U.S. Environmental Protection Agency.

Cliver, D. O. (1981). Experimental infection by waterborne enteroviruses. Journal of Food Protection, 44, 861-865.

Cliver, D. O. (1983). Manual on food virology, VPH/83.46 World Health Organization, Geneva.

Cliver, D. O. (1984). Viruses and on site wastewater treatment. (R2740) Small Scale Waste Management Project. Madison, WI: University of Wisconsin.

Cliver, D. O., \& Bohl, E. H. (1962a). Isolation of enteroviruses from a herd of dairy cattle. Journal of Dairy Science, 45, 921-925.

Cliver, D. O., \& Bohl, E. H. (1962b). Neutralization of bovine enteroviruses by colostrum, milk and blood serum. Journal of Dairy Science, 45, 926-932.

Cliver, D. O., Ellender, R. D., Fout, G. S., Shields, P. A., \& Sobsey, M. D. (1992). Foodborne viruses. In S. C. Vanderzant \& D. F. Splittstoesser (Eds.), Compendium of methods for the microbiological examination of foods (3rd ed., pp. 763-787). Washington, DC: American Public Health Association.

Cliver, D. O., Ellender, R. D., \& Sobsey, M. D. (1983a). Methods for detecting viruses in foods: Background and general principles. Journal of Food Protection, 46, 248-259.

Cliver, D. O., Ellender, R. D., \& Sobsey, M. D. (1983b). Methods to detect viruses in foods: Testing and interpretation of results. Journal of Food Protection, 46, 345-357.

Cliver, D. O., Ellender, R. D., \& Sobsey, M. D. (1984). Foodborne viruses. In M. L. Speck (Ed.), Compendium of methods for the microbiological examination of foods (2nd ed., pp. 508-5410). Washington, DC: American Public Health Association.

Cliver, D. O., Green, K. M., \& Bouma, J. (1975). Viruses and septic tank effluent. R2740, University of Wisconsin College of Agriculture and Life Sciences Research Report, Madison, WI.

Cliver, D. O., \& Grindrod, J. (1969). Surveillance methods for viruses in foods. Journal of Milk and Food Technology, 32, 421-425.

Cliver, D. O., \& Herrmann, R. M. (1969). Economical tissue culture technics. Health Laboratory Science, 6, 5-17.

Cliver, D. O., \& Herrmann, J. E. (1972). Proteolytic and microbial inactivation of enteroviruses. Water Research, 6, 797-805.

Cliver, D. O., \& Kostenbader, K. D., Jr. (1979). Antiviral effectiveness of grape juice. Journal of Food Protection, 42, 100-104.

Cliver, D. O., \& Kostenbader, K. D., Jr. (1984). Disinfection of virus on hands for prevention of food-borne disease. Internation Journal of Food Microbiology, 1, 75-87.

Cliver, D. O., Kostenbader, K. D., Jr., \& Vallenas, M. R. (1970). Stability of viruses in low moisture foods. Journal of Milk and Food Technology, 33, 484-491.

Cliver, D. O., \& Newman, R. A. (1984). Drinking water microbiology, NATO/CCMS Drinking Water Pilot Project Series (CCMS 128), Committee on the Challenges of Modern Society. Washington, DC: US Environmental Protection Agency, Office of Drinking Water, xxxii $+545 \mathrm{pp}$.

Cliver, D. O., \& Newman, R. A. (1987). Drinking-water microbiology. Journal of Environmental Pathology Toxicology and Oncology, 7, xxxiv +365 pp.
Cliver, D. O., \& Yeatman, J. (1965). Ultracentrifugation in the concentration and detection of enteroviruses. Applied Microbiology, 13, 387-392.

Cromeans, T., Nainan, O. V., Fields, H. A., Favorov, M. O., \& Margolis, H. S. (1994). Hepatitis A and E viruses. In Y. H. Hui, J. R. Gorham, K. D. Murrell, \& D. O. Cliver (Eds.), Foodborne disease handbook: Vol. 2. Diseases caused by viruses, parasites, and fungi (pp. 1-56). New York: Marcel Dekker, Inc.

Cromeans, T., Sobsey, M. D., \& Fields, H. A. (1987). Development of a plaque assay for a cytopathic, rapidly replicating isolate of hepatitis A virus. Journal of Medical Virology, 22, 45-56.

Deng, M. Y., \& Cliver, D. O. (1984). A broad-spectrum enzymelinked immunosorbent assay for the detection of human enteric viruses. Journal of Virological Methods, 8, 87-98.

Deng, M. Y., \& Cliver, D. O. (1992). Inactivation of poliovirus type 1 in mixed human and swine wastes and by bacteria from swine manure. Applied and Environmental Microbiology, 58, 20162021.

Deng, M. Y., \& Cliver, D. O. (1995a). Antiviral effects of bacteria isolated from manure. Microbial Ecology, 30, 43-45.

Deng, M. Y., \& Cliver, D. O. (1995b). Persistence of inoculated hepatitis A virus in mixed human and animal wastes. Applied and Environmental Microbiology, 61, 87-91.

Deng, M. Y., Day, S. P., \& Cliver, D. O. (1994). Detection of hepatitis A virus in environmental samples by antigen-capture PCR. Applied and Environmental Microbiology, 60, 1927-1933.

Derbyshire, J. B., \& Collins, A. P. (1971). The multiplication of Talfan virus in pig intestinal organ cultures. Research in Veterinary Science, 12, 367-370.

Dolin, R., Blacklow, N. R., Mahagren, R. A., \& Chanock, R. M. (1971). Establishment of human fetal intestinal organ cul tures for growth of viruses. Journal of Infectious Dissease, 122, 227-231.

Dolin, R., Blacklow, N. R., Wyatt, R. G., \& Sereno, M. M. (1972). Detection and localization of viruses in human fetal intestinal organ cultures by immunofluorescence. Infection and Immunity, 6, 958-964.

Duizer, E., Schwab, K. J., Neill, F. H., Atmar, R. L., Koopmans, M. P., \& Estes, M. K. (2004). Laboratory efforts to cultivate noroviruses. Journal of General Virology, 85, 79-87.

EPA. (2001). US EPA manual of methods for virology. Cincinnati: US Environmental Protection Agency.

Erdtmann, R., \& Sivitz, L. B. (Eds.). (2004). Advancing prion science. Guidance for the National Prion Research Program. Washington, DC: National Academies Press.

Fugate, K. J., Cliver, D. O., \& Hatch, M. T. (1975). Enteroviruses and potential bacterial indicators in Gulf Coast oysters. Journal of Milk and Food Technology, 38, 100-104.

Gary, G. W., Anderson, L. J., Keswick, B. H., Johnson, P. C., DuPont, H. L., Stine, S. E., et al. (1987). Norwalk virus antigen and antibody response in an adult volunteer study. Journal of Clinical Microbiology, 25, 2001-2003.

Gibbs, T., \& Cliver, D. O. (1965). Methods for detecting minimal contamination with reovirus. Health Laboratory Science, 57, 81-88.

Green, K. M., \& Cliver, D. O. (1975). Removal of virus from septic tank effluent by sand columns. In Proceedings of the national home sewage disposal symposium (pp. 137-143). St. Joseph, MI: American Society of Agricultural Engineers.

Grindrod, J., \& Cliver, D. O. (1969). Limitations of the polymer two phase system for detection of viruses. Archiv für die Gesamte Virusforschung, 28, 337-347.

Grindrod, J., \& Cliver, D. O. (1970). A polymer two phase system adapted to virus detection. Archiv für die Gesamte Virusforschung, 31, 365-372.

Grohmann, G. S., Murphy, A. M., Christopher, P. J., Auty, E., \& Greenberg, H. B. (1981). Norwalk virus gastroenteritis in 
volunteers consuming depurated oysters. Australian Journal of Experimental Biology and Medical Science, 59, 219-228.

Hajmeer, M. N., Cliver, D. O., \& Marsden, J. L. (2006). Central nervous system tissue detection in meat from advanced meat recovery systems. Meat Science, 72, 656-659.

Hajmeer, M., Cliver, D. O., \& Provost, R. (2003). Spinal cord tissue detection in comminuted beef: Comparison of two immunological methods. Meat Science, 65, 757-763.

Heinz, B. A., \& Cliver, D. O. (1988). Coxsackievirus-cell interactions that initiate infection in porcine ileal explants. Archives of Virology, 101, 35-47.

Heinz, B. A., Cliver, D. O., \& Donohoe, B. (1987). Enterovirus replication in porcine ileal explants. Journal of General Virology, 68(Pt 9), 2495-2499.

Heinz, B. A., Cliver, D. O., \& Hehl, G. L. (1986). Enumeration of enterovirus particles by scanning electron microscopy. Journal of Virological Methods, 14, 71-83.

Herrmann, J. E., \& Cliver, D. O. (1968a). Food-borne virus: Detection in a model system. Applied Microbiology, 16, 595-602.

Herrmann, J. E., \& Cliver, D. O. (1968b). Methods for detecting foodborne enteroviruses. Applied Microbiology, 16, 1564-1569.

Herrmann, J. E., \& Cliver, D. O. (1973a). Degradation of coxsackievirus type A9 by proteolytic enzymes. Infection and Immunity, 7 , 513-517.

Herrmann, J. E., \& Cliver, D. O. (1973b). Enterovirus persistence in sausage and ground beef. Journal of Milk and Food Technology, $36,426-428$.

Herrmann, J. E., \& Cliver, D. O. (1973c). Rapid method to determine labeling specificity of radioactive enteroviruses. Applied Microbiology, 25, 313-314.

Herrmann, J. E., Hendry, R. M., \& Collins, M. F. (1979). Factors involved in enzyme-linked immunoassay of viruses and evaluation of the method for identification of enteroviruses. Journal of Clinical Microbiology, 10, 210-217.

Herrmann, J. E., Kostenbader, K. D., Jr., \& Cliver, D. O. (1974). Persistence of enteroviruses in lake water. Applied Microbiology, 28, 895-896.

Hoshino, Y., \& Scott, F. W. (1980). Immunofluorescent and electron microscopic studies of feline small intestinal organ cultures infected with feline infectious peritonitis virus. American Journal of Veterinary Research, 41, 672-881.

Hsiung, G. D. (1965). Use of ultrafiltration for animal virus grouping. Bacteriological Reviews, 29, 477-486.

Hsiung, G. D., \& Henderson, J. R. (1964). Diagnostic virology. New Haven, CT: Yale University Press.

Jensen, J. L., \& Cliver, D. O. (1984). Enterovirus replication in ileal explants. Annals of Virology, 135, 137-143.

Johnson, J. S., \& Cliver, D. O. (1986). Coliphages as indicators of fecal and viral contamination of groundwater. In Proceedings of ninth annual Madison waste conference (pp. 85-95). Madison, WI: Dept. Engineering Professional Development, University of Wisconsin Madison.

Johnson, K. M., Cooper, R. C., \& Straube, D. C. (1981). Procedure for recovery of enteroviruses from the Japanese cockle Tapes japonica. Applied and Environmeatal Microbiology, 41, 932-935.

Jothikumar, N., \& Cliver, D. O. (1997). Elution and reconcentration of coliphages in water from positively charged membrane filters with urea-arginine phosphate buffer. Journal of Virological Methods, 65, 281-286.

Jothikumar, N., \& Cliver, D. O. (1998). Fluorescent Escherichia coli $\mathrm{C}$ for enumeration of coliphages from environmental samples. Biotechniques, 24, 546, 550.

Jothikumar, N., Cliver, D. O., \& Mariam, T. W. (1998). Immunomagnetic capture PCR for rapid concentration and detection of hepatitis A virus from environmental samples. Applied and Environmental Microbiology, 64, 504-508.
Jubb, G. (1915). A third outbreak of epidemic poliomyelitis at West Kirby. Lancet, 1, 67.

Kalitina, T. A. (1966). Persistence of coxsackie group B types 3 and 5 in mince meat (in Russian). Voprosy Pitaniya, 5, 74-77.

Kalitina, T. A. (1969). Study of the transmissibility of enteroviruses in milk and milk products (in Russian). Zhurnal Mikrobiologii Epidemiologii Immunobiologii, 7, 61-64.

Kaplan, H. S., \& Moses, L. E. (1964). Biological complexity and radiosensitivity. Radiation lethality in cells and viruses is correlated with nucleic acid content, structure, and ploidy. Science, 145, 21-25.

Kasza, L. (2003). Hardships and joys of an exiled cancer researcher. Bloomington, IN: Authorhouse.

Koff, R. S., Grady, G. F., Chalmers, T. C., Mosley, J. W., Swartz, B. L., \& the Boston Inter-Hospital Liver Group. (1967). Viral hepatitis in a group of Boston hospitals. III. Importance of exposure to shellfish in a nonepidemic period. New England Journal of Medicine, 276, 703-710.

Konowalchuk, J., \& Speirs, J. I. (1976a). Antiviral activity of fruit extracts. Journal of Food Science, 41, 1013-1017.

Konowalchuk, J., \& Speirs, J. I. (1976b). Virus inactivation by grapes and wines. Applied and Environmental Microbiology, 32, $757-763$.

Konowalchuk, J., \& Speirs, J. I. (1978a). Antiviral effect of apple beverages. Applied and Environmental Microbiology, 36, 798-801.

Konowalchuk, J., \& Speirs, J. I. (1978b). Antiviral effect of commercial juices and beverages. Applied and Environmental Microbiology, 35, 1219-1220.

Konowalchuk, J., Speirs, J. I., \& Stavric, S. (1977). Vero response to a cytotoxin of Escherichia coli. Infection and Immunity, 18, 775-779.

Kostenbader, K. D., Jr., \& Cliver, D. O. (1972). Polyelectrolyte flocculation as an aid to recovery of enteroviruses from oysters. Applied Microbiology, 24, 540-543.

Kostenbader, K. D., Jr., \& Cliver, D. O. (1973). Filtration methods for recovering enteroviruses from foods. Applied Microbiology, 26, 149-154.

Kostenbader, K. D., Jr., \& Cliver, D. O. (1977). Quest for viruses associated with our food supply. Journal of Food Science, 42, 1253-1257, 1268.

Kostenbader, K. D., Jr., \& Cliver, D. O. (1979). Purchased cell culture for detecting foodborne viruses. Journal of Food Protection, 42, $888-889$.

Kostenbader, K. D., Jr., \& Cliver, D. O. (1981). Flocculants for recovery of food-borne viruses. Applied and Environmental Microbiology, 41, 318-320.

Kostenbader, K. D., Jr., \& Cliver, D. O. (1986). Reactivation with pancreatin of coproantibody-neutralized virus in ground beef. Journal of Food Protection, 49, 920-923.

Landry, E. F., Vaughn, J. M., Vicale, T. J., \& Mann, R. (1982). Inefficient accumulation of low levels of monodispersed and feces-associated poliovirus in oysters. Applied and Environmental Microbiology, 44, 1362-1369.

Lewis, G. D., \& Metcalf, T. G. (1988). Polyethylene glycol precipitation for recovery of pathogenic viruses, including hepatitis A virus and human rotavirus, from oyster, water, and sediment samples. Applied and Environmental Microbiology, 54, 1983-1988.

Licciardello, J. J., D’Entremont, D. L., \& Lundstrom, R. C. (1989). Radio-resistance of some bacterial pathogens in soft-shell clams Mya-arenaria and mussels Mytilus-edulis. Journal of Food Protection, 52, 407-411.

López-Sabater, E. I., Deng, M. Y., \& Cliver, D. O. (1997). Magnetic immunoseparation PCR assay (MIPA) for detection of hepatitis A virus (HAV) in American oyster (Crassostrea virginica). Letters in Applied Microbiology, 24, 101-104. 
Lund, E., \& Hedstrom, C. E. (1966). The use of an aqueous polymer phase system for enterovirus isolations from sewage. American Journal of Epidemiology, 84, 287-291.

Lund, E., \& Hedstrom, C.-E. (1967). Recovery of viruses from a sewage treatment plant. In G. Berg (Ed.), Transmission of viruses by the water route (pp. 371-377). New York: Interscience.

Lynt, R. K., Jr. (1966). Survival and recovery of enterovirus from foods. Applied Microbiology, 14, 218-222.

Mallett, J. C., Beghian, L. E., Metcalf, T. G., \& Kaylor, J. D. (1991). Potential of irradiation technology for improved shellfish sanitation. Journal of Food Safety, 11, 231-245.

Mariam, T. W., \& Cliver, D. O. (2000a). Hepatitis A virus control in strawberry products. Dairy Food and Environmental Sanitation, 20, 612-616.

Mariam, T. W., \& Cliver, D. O. (2000b). Small round coliphages as surrogates for human viruses in process assessment. Dairy Food and Environmental Sanitation, 20, 684-689.

Marionneau, S., Ruvoen, N., Le Moullac-Vaidye, B., Clement, M., Cailleau-Thomas, A., Ruiz-Palacois, G., et al. (2002). Norwalk virus binds to histo-blood group antigens present on gastroduodenal epithelial cells of secretor individuals. Gastroenterology, 122, 1967-1977.

Mbithi, J. N., Springthorpe, V. S., Boulet, J. R., \& Sattar, S. A. (1992). Survival of hepatitis A virus on human hands and its transfer on contact with animate and inanimate surfaces. Journal of Clinical Microbiology, 30, 757-763.

Mbithi, J. N., Springthorpe, V. S., \& Sattar, S. A. (1993). Comparative in vivo efficiencies of hand-washing agents against hepatitis A virus (HM-175) and poliovirus type 1 (Sabin). Journal of Clinical Microbiology, 59, 3463-3469.

Metcalf, T. G., Eckerson, D., \& Moulton, E. (1980a). A method for recovery of viruses from oysters and hard and soft shell clams. Journal of Food Protection, 43, 89-90.

Metcalf, T. G., Eckerson, D., Moulton, E., \& Larkin, E. P. (1980b). Uptake and depletion of particulate-associated polioviruses by the soft shell clam. Journal of Food Protection, 43, 87-88.

Metcalf, T. G., Melnick, J. L., \& Estes, M. K. (1995). Environmental virology: From detection of virus in sewage and water by isolation to identification by molecular biology-A trip of over 50 years. Annual Review of Microbiology, 49, 461-487.

Metcalf, T. G., Mullin, B., Eckerson, D., Moulton, E., \& Larkin, E. P. (1979). Bioaccumulation and depuration of enteroviruses by the soft-shelled clam, Mya arenaria. Applied and Environmental Microbiology, 38, 275-282.

Metcalf, T. G., \& Stiles, W. C. (1965). The accumulation of enteric viruses by the oyster, Crassostrea virginica. Journal of Infectious Disease, 115, 68-76.

Metcalf, T. G., \& Stiles, W. C. (1967). Survival of enteric viruses in estuary water and shellfish. In G. Berg (Ed.), Transmission of viruses by the water route (pp. 439-447). New York: Interscience (John Wiley \& Sons).

Metcalf, T. G., \& Stiles, W. C. (1968). Enteroviruses within an estuarine environment. American Journal of Epidemiology, 88, 379-391.

Mosley, J. W. (1967). Transmission of viral diseases by drinking water. In G. Berg (Ed.), Transmission of viruses by the water route (pp. 5-23). New York: Interscience.

Nuanualsuwan, S., \& Cliver, D. O. (2002). Pretreatment to avoid positive RT-PCR results with inactivated viruses. Journal of Virological Methods, 104, 217-225.

Nuanualsuwan, S., \& Cliver, D. O. (2003a). Capsid functions of inactivated human picornaviruses and feline calicivirus. Applied and Environmental Microbiology, 69, 350-357.

Nuanualsuwan, S., \& Cliver, D. O. (2003b). Infectivity of RNA from inactivated poliovirus. Applied and Environmental Microbiology, 69, 1629-1632.
Nuanualsuwan, S., Mariam, T., Himathongkham, S., \& Cliver, D. O. (2002). Ultraviolet inactivation of feline calicivirus, human enteric viruses and coliphages. Photochemistry and Photobiology, 76, 406-410.

Olivieri, V. P., Hauchman, F. S., Noss, C. I., Vasl, R., Neeper, M. P., \& Cliver, D. O. (1983). Mode of action of chlorine dioxide on selected bacterial and enteric viruses. In M. Butler, A. R. Medlen, \& R. Morris (Eds.), Viruses and disinfection of water and wastewater (pp. 261-281). Guildford, England: University of Surrey Print Unit.

Philipson, L., Albertsson, P. A., \& Frick, G. (1960). The purification and concentration of viruses by aqueous polymer phase systems. Virology, 11, 553-571.

Plowright, C. B. (1896). On an epidemic of jaundice in King's Lynn, 1895. British Medical Journal, 1, 1321.

Power, U. F., \& Collins, J. K. (1989). Differential depuration of poliovirus, Escherichia coli, and a coliphage by the common mussel, Mytilus edulis. Applied and Environmental Microbiology, 55, 1386-1390.

Provost, P. J., \& Hilleman, M. R. (1979). Propagation of human hepatitis A virus in cell culture in vitro. In Proceedings of the Society for Experimental Biology and Medicine, 160, 213-221.

Richards, G. P., \& Cliver, D. O. (2001). Foodborne viruses. In F. P. Downes \& K. Ito (Eds.), Compendium of methods for the microbiological examination of foods (4th ed., pp. 447-461). Washington, DC: Am. Pub. Health Assoc.

Richards, G. P., Goldmintz, D., Green, D. L., \& Babinchak, J. A. (1982). Rapid methods for extraction and concentration of poliovirus from oyster tissues. Journal of Virological Methods, 5, 285-291.

Rodriguez, R. A., Pepper, I. L., \& Gerba, C. P. (2009). Application of PCR-based methods to assess the infectivity of enteric viruses in environmental samples. Applied and Environmental Microbiology, 75, 297-307.

Rubenstein, D., \& Tyrrell, D. A. J. (1970). Growth of viruses in organ cultures of intestine. British Journal of Experimental Pathology, $51,210-216$.

Rubenstein, D., Tyrrell, D. A. J., Derbyshire, J. B., \& Collins, A. P. (1970). Growth of porcine transmissible gastroenteritis (TGE) virus in organ cultures of pig tissue. Nature, 227, 1348-1349.

Rzezutka, A., \& Cook, N. (2004). Survival of human enteric viruses in the environment and food. FEMS Microbiolical Reviews, 28, 441-453.

Salo, R. J., \& Cliver, D. O. (1976). Effect of acid pH, salts, and temperature on the infectivity and physical integrity of enteroviruses. Archives of Virology, 52, 269-282.

Salo, R. J., \& Cliver, D. O. (1978). Inactivation of enteroviruses by ascorbic acid and sodium bisulfite. Applied and Environmental Microbiology, 36, 68-75.

Sattar, S. A., \& Ansari, S. A. (2002). The fingerpad protocol to assess hygienic hand antiseptics against viruses. Journal of Virological Methods, 103, 171-181.

Schiff, G. M., Stefanovic, G. M., Young, E. C., Sander, D. S., Pennekamp, J. K., \& Ward, R. L. (1984). Studies of echovirus-12 in volunteers: Determination of minimal infectious dose and the effect of previous infection on infectious dose. Journal of Infectious Disease, 150, 858-866.

Seidel, K. M., Goyal, S. M., Rao, V. C., \& Melnick, J. L. (1983). Concentration of rotavirus and enteroviruses from blue crabs (Callinectes sapidus). Applied and Environmental Microbiology, 46, 1293-1296.

Sharp, D. G. (1967). Electron microscopy and viral particle function. In G. Berg (Ed.), Transmission of viruses by the water route (pp. 193-217). New York: Interscience.

Shuval, H. I., Cymbalista, S., Fatal, B., \& Goldblum, N. (1967). Concentration of enteric viruses in water by hydro-extraction 
and two-phase separation. In G. Berg (Ed.), Transmission of viruses by the water route (pp. 45-55). New York: Interscience.

Snowdon, J. A., \& Cliver, D. O. (1989). Coliphages as indicators of human enteric viruses in groundwater. Critical Reviws in Environmental Control, 19, 231-249.

Snowdon, J. A., Cliver, D. O., \& Converse, J. C. (1989a). Inactivation of poliovirus-1, as a function of temperature, in mixed human and dairy animal wastes. Waste Management Research, 7, 135-142.

Snowdon, J. A., Cliver, D. O., \& Converse, J. C. (1989b). Land disposal of mixed human and animal wastes-A review. Waste Management Research, 7, 121-134.

Sobsey, M. D., Battigelli, D. A., Shin, G. A., \& Newland, S. (1998). RT-PCR amplification detects inactivated viruses in water and wastewater. Water Science and Technology, 38, 91-94.

Speirs, J. I., Stavric, S., \& Konowalchuk, J. (1977). Assay of Escherichia coli heat-labile enterotoxin with vero cells. Infection and Immunity, 16, 617-622.

Stramer, S. L. (1984). Fates of poliovirus and enteric indicator bacteria during treatment in a septic tank system including septage disinfection. Ph.D. dissertation, University of Wisconsin, Madison.

Stramer, S. L., \& Cliver, D. O. (1984). Septage treatments to reduce the numbers of bacteria and polioviruses. Applied and Environmental Microbiology, 48, 566-572.

Sullivan, R., Fassolitis, A. C., Larkin, E. P., Read, R. B., Jr., \& Peeler, J. T. (1971). Inactivation of thirty viruses by gamma radiation. Applied Microbiology, 22, 61-65.

Sullivan, R., Scarpino, P. V., Fassolitis, A. C., Larkin, E. P., \& Peeler, J. T. (1973). Gamma radiation inactivation of coxsackievirus B-2. Applied Microbiology, 26, 14-17.
Teunis, P. F., Lodder, W. J., Heisterkamp, S. H., \& de Roda Husman, A. M. (2005). Mixed plaques: Statistical evidence how plaque assays may underestimate virus concentrations. Water Research, $39,4240-4250$.

Wait, D. A., \& Sobsey, M. D. (1983). Method for recovery of enteric viruses from estuarine sediments with chaotropic agents. Applied and Environmental Microbiology, 46, 379-385.

Warriner, R., Kostenbader, K. D., Jr., Cliver, D. O., \& Ku, W.-C. (1985). Disinfection of advanced wastewater treatment effluent by chlorine, chlorine dioxide and ozone. Experiments using seeded poliovirus. Water Research, 19, 1515-1526.

Wilson, J. N., \& Cooper, P. D. (1965). The effect of light on poliovirus grown in neutral red. Virology, 26, 1-9.

Woody, M. A., \& Cliver, D. O. (1994). FRNA coliphages for monitoring groundwater near on-site systems. In E. Collins (Ed.), On-site wastewater treatment (pp. 551-558). Proceedings of the seventh international symposium on individual and small community sewage systems. Dec. 11-13, 1994. Atlanta, GA.

Woody, M. A., \& Cliver, D. O. (1995). Effects of temperature and host cell growth phase on replication of F-specific RNA coliphage Q beta. Applied and Environmental Microbiology, $61,1520-1526$.

Woody, M. A., \& Cliver, D. O. (1997). Replication of coliphage Q beta as affected by host cell number, nutrition, competition from insusceptible cells and non-FRNA coliphages. Journal of Applied Microbiology, 82, 431-440.

Wyatt, R. G., Kalica, A. R., \& Dolin, R. (1973). Ultrastructural study of viral replication in human fetal intestinal organ culture. Archiv für die Gesamte Virusforschung, 40, 341-349. 